\title{
High-Spin Iron(II) as a Semitransparent Partner for Tuning Europium(III) Luminescence in Heterodimetallic d-f Complexes
}

\author{
Carine Edder, ${ }^{[a]}$ Claude Piguet, ${ }^{*[a]}$ Jean-Claude G. Bünzlii, ${ }^{[b]}$ and Gérard Hopfgartner ${ }^{[c]}$
}

\begin{abstract}
The segmental ligand 2-\{6( $N, N$-diethylcarbamoyl)pyridin-2-yl\}-1,1'dimethyl-5,5'-methylene-2'-(6-methylpyridine-2-yl)bis[1 $H$-benzimidazole] $\left(\mathrm{L}^{3}\right)$ reacts with a stoichiometric mixture of $\mathrm{Ln}^{\mathrm{III}}(\mathrm{Ln}=\mathrm{La}, \mathrm{Eu}, \mathrm{Gd})$ and $\mathrm{M}^{\mathrm{II}}(\mathrm{M}=$ $\mathrm{Zn}, \mathrm{Fe})$ in acetonitrile to produce selectively the heterodimetallic triple-stranded helicates $(\mathrm{HHH})-\left[\operatorname{LnM}\left(\mathrm{L}^{3}\right)_{3}\right]^{5+}$. In these complexes, $\mathrm{M}^{\mathrm{II}}$ is pseudooctahedrally coordinated by the three wrapped bidentate binding units, thus forming a noncovalent tripod which organizes the three unsymmetrical tridentate segments to give ninefold coordination to $\mathrm{Ln}^{\text {III. }}$. The introduction of a methyl group at the 6 position of the terminal pyridine in $\mathrm{L}^{3}$ sterically reduces the complexing ability of the bidentate segment for $\mathrm{M}^{\mathrm{II}}$.
\end{abstract}

Spectroscopic (ESI-MS, UV/Vis/NIR, NMR), magnetic and electrochemical measurements show that 1) the head-tohead-to-head triple helical complexes $(\mathrm{HHH})-\left[\mathrm{LnM}\left(\mathrm{L}^{3}\right)_{3}\right]^{5+}$ are quantitatively formed in solution only for ligand concentrations larger than $0.01 \mathrm{M}, 2) \mathrm{Fe}^{\mathrm{II}}$ adopts a pure high-spin electronic configuration in $(\mathrm{HHH})-\left[\mathrm{LnFe}\left(\mathrm{L}^{3}\right)_{3}\right]^{5+}$, and 3) the $\mathrm{Fe}^{\mathrm{II}} / \mathrm{Fe}^{\mathrm{III}}$ oxidation process is prevented by steric constraints. Detailed photophysical studies of $(\mathrm{HHH})-[\mathrm{Eu}-$ $\left.\mathrm{Zn}\left(\mathrm{L}^{3}\right)_{3}\right]^{5+}$ confirm that the pseudotri-

Keywords: energy transfer • iron • helical structures - heterodimetallic complexes lanthanides capped trigonal-prismatic lanthanide coordination site is not affected by the methyl groups bound to the terminal pyridine, thus leading to significant Eucentered emission upon UV irradiation. In $(\mathrm{HHH})-\left[\mathrm{EuFe}\left(\mathrm{L}^{3}\right)_{3}\right]^{5+}$, a resonant intramolecular $\mathrm{Eu} \rightarrow \mathrm{Fe}^{\mathrm{II}}$ hs energy transfer partially quenches the Eu-centered luminescence; however, the residual red emission demonstrates that high-spin iron(II) is compatible with the sensitization of $\mathrm{Eu}^{\mathrm{III}}$ in heterodimetallic $\mathrm{d}-\mathrm{f}$ complexes. The influence of the electronic configuration of $\mathrm{Fe}^{\mathrm{II}}$ on the efficiency of $\mathrm{Eu}^{\mathrm{III}} \rightarrow \mathrm{Fe}^{\mathrm{II}}$ energy-transfer processes is discussed together with its consequence for the design of optically active spin-crossover supramolecular devices.

\section{Introduction}

The selective introduction of one d- and one f-block ion into the same molecular or supramolecular edifice has attracted

[a] Prof. Dr. C. Piguet, C. Edder

Department of Inorganic, Analytical and Applied Chemistry University of Geneva

30 quai E. Ansermet, 1211 Geneva 4 (Switzerland)

Fax: $(+41) 22702-6830$

E-mail: Claude.Piguet@chiam.unige.ch

[b] Prof. Dr. J.-C. G. Bünzli

Institute of Inorganic and Analytical Chemistry

University of Lausanne

BCH 1402, 1015 Lausanne (Switzerland)

[c] Dr. G. Hopfgartner

F. Hoffmann - La Roche Ltd, Pharmaceuticals Division PRNS 68/142, 4070 Basle (Switzerland)

Supporting information for this article is available on the WWW under http://www.wiley-vch.de/home/chemistry/ or from the author. Table S1 lists ${ }^{1} \mathrm{H}$ NMR shifts, Table S2 lists the ES-MS peaks observed during titrations and Table $\mathrm{S} 3$ lists integrated luminescence intensities and main identified $\mathrm{Eu}\left({ }^{7} \mathrm{~F}_{\mathrm{j}}\right)$ energy levels for $\left[\mathrm{EuZn}\left(\mathrm{L}^{3}\right)_{3}\right]\left(\mathrm{ClO}_{4}\right)_{5} \cdot \mathrm{H}_{2} \mathrm{O}(\mathbf{5})$ in the solid state. much attention for the elucidation of weak magnetic interactions mediated either by direct overlaps between the metallic orbitals or by superexchange pathways. ${ }^{[1]}$ Less interest has been focused on intermetallic $\mathrm{d}-\mathrm{f}$ communication mediated by mechanical coupling between the coordination sites $^{[2]}$ or by intramolecular energy transfers. ${ }^{[3]}$ The exchange mechanism proposed by Dexter ${ }^{[4]}$ implies a double-electron exchange between donor and acceptor which critically depends on orbital overlaps. It is thus limited to short distances and involves the atoms (or ligands) directly coordinated to $\mathrm{Ln}^{\mathrm{III}}{ }^{[5]}$ At larger distances, through-space multipolar Förster-type mechanisms ${ }^{[6]}$ are invoked to rationalize $\mathrm{d} \leftrightarrow \mathrm{f}$ energy transfers which are then controlled by spectral overlaps between the emission spectrum of the donor and the absorption spectrum of the acceptor. ${ }^{[7]}$ Förster energy transfers that are limited to dipole - dipole interactions have been extensively used to estimate the distance between fixed or rapidly diffusing $\mathrm{d}-\mathrm{f}$ or $\mathrm{f}-\mathrm{f}$ pairs in several heterodimetallic edifices, but only few systematic variations of the acceptor have been reported, except for $\mathrm{Cr}^{\mathrm{III}}$ and $\mathrm{Co}^{\mathrm{III}}$ ions which possess adequate energy levels for the efficient quenching of $\mathrm{Eu}^{\mathrm{III}}$ or $\mathrm{Tb}^{\mathrm{III}}$ luminescence. ${ }^{[3,8]} \operatorname{Iron}(\mathrm{II})\left(\mathrm{d}^{6}\right)$ is a promising 
versatile acceptor in heterodimetallic $\mathrm{d}-\mathrm{f}$ complexes because it displays two different electronic configurations with different optical characteristics depending on the ligand field strength in pseudooctahedral complexes (i.e. diamagnetic low-spin $\left({ }^{1} \mathrm{~A}_{1}\right.$ in $O_{\mathrm{h}}$ symmetry) and paramagnetic high-spin $\left.\left({ }^{5} \mathrm{~T}_{2}\right)\right) \cdot{ }^{[9]}$ Low-spin iron(II) $\left(\mathrm{Fe}^{\mathrm{II}}{ }_{\mathrm{ls}}\right)$ in $\left[\mathrm{Fe}\left(\alpha, \alpha^{\prime} \text {-diimine }\right)_{3}\right]^{2+}$ and in $\left[\mathrm{Fe}(\text { terimine })_{2}\right]^{2+}$ complexes displays an intense metal-toligand charge-transfer (MLCT) transition at $\approx 18000 \mathrm{~cm}^{-1}$ which is responsible for the red to violet color of the complexes, together with $\mathrm{d}-\mathrm{d}$ transitions of weaker intensities in the same energy domain. ${ }^{[10]}$ A weaker MLCT transition is found at significantly higher energy $\left(\approx 25000 \mathrm{~cm}^{-1}\right)$ for related yellow to orange high-spin iron(II) $\left(\mathrm{Fe}^{\mathrm{II}}{ }_{\mathrm{hs}}\right)$ complexes, while the $\mathrm{d}-\mathrm{d}$ transitions are shifted toward lower energy and appear in the near-IR domain. ${ }^{[10,11]}$ According to these characteristics, we expect that resonant $\mathrm{Eu}^{\mathrm{III}} \rightarrow \mathrm{Fe}^{\mathrm{II}}$ energy transfers will strongly depend on the spin state of iron(II) to lead to a precise control of the Eu-centered emission by the remote d-block ion. Since spin-crossover processes in pseudooctahedral iron(II) complexes with $\alpha, \alpha^{\prime}$ diimine ligands can be triggered by various external stimuli (temperature, pressure, light),${ }^{[9,12]}$ it would be theoretically possible to use $\mathrm{Eu}^{\mathrm{III}}$ as an internal reporter of these changes, as recently described for related $\mathrm{Eu}, \mathrm{Tb}$, and $\mathrm{Yb}$ complexes that function as luminescent probes for the quantitative detection of analytes $\left(\mathrm{O}_{2}, \mathrm{H}^{+}, \mathrm{Cl}^{-}, \mathrm{OH}^{-}, \mathrm{Na}^{+} \text {, acetate, etc. }\right)^{[13]}$ We have recently reported that $\mathrm{Fe}^{\mathrm{II}}$ displays a thermally induced spin-transition in the heterodimetallic complexes $(\mathrm{HHH})-\left[\mathrm{LnFe}\left(\mathrm{L}^{1}\right)_{3}\right]^{5+}($ Scheme 1$)$, with a critical temperature $T_{\mathrm{C}}$ around room temperature. ${ }^{[2]}$ The minor variations in the
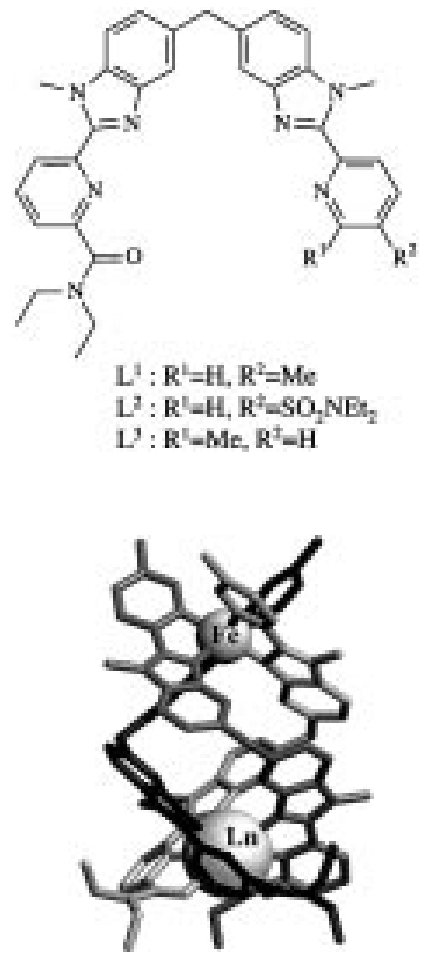

(HHH)- (LAFe(L) $\left.)_{3}\right\}^{5+}$

Scheme 1. The ligands $\mathrm{L}^{1}-\mathrm{L}^{3}$ (top) and the heterodimetallic complex $(\mathrm{HHH})-\left[\mathrm{LnFe}\left(\mathrm{L}^{1}\right)_{3}\right]^{5+}$ (bottom). size of $\mathrm{Ln}^{\mathrm{III}}$ along the lanthanide series allows the fine tuning of the thermodynamic parameters of the spin-state equilibria. However, an efficient intramolecular $\mathrm{Eu}^{\mathrm{III}} \rightarrow \mathrm{Fe}^{\mathrm{II}}$ ls energy transfer precludes the detection of Eu-centered luminescence, even at the highest accessible temperature for which the fraction of $\mathrm{Fe}^{\mathrm{II}}{ }_{\mathrm{hs}}$ is maximum $(>0.5){ }^{[2]}$ To investigate $\mathrm{Eu}^{\mathrm{III}} \rightarrow$ $\mathrm{Fe}^{\mathrm{II}}{ }_{\text {hs }}$ energy transfer processes in these systems, pure highspin $\mathrm{Fe}^{\mathrm{II}}$ complexes that contain a noncovalent tripod at room temperature must be prepared. As a first attempt toward this goal, we connected an electron-withdrawing sulfonamide group at the 5 position of the pyridine ring of the bidentate segment in $\mathrm{L}^{2}$ to reduce the ligand-field strength of the $\mathrm{Fe}^{\mathrm{II}}$ coordination site in $(\mathrm{HHH})-\left[\mathrm{LnFe}\left(\mathrm{L}^{2}\right)_{3}\right]^{5+}$. Unfortunately, $\sigma / \pi$ compensating effects produced only a minor decrease of $T_{\mathrm{c}}$ $\left(\Delta T \approx 20 \mathrm{~K}\right.$ with respect to $\left.(\mathrm{HHH})-\left[\mathrm{LnFe}\left(\mathrm{L}^{1}\right)_{3}\right]^{5+}\right)$ which was incompatible with the production of pure high-spin $\mathrm{Fe}^{\mathrm{II}}$ tripods. ${ }^{[2]}$ We report herein an alternative approach in which the connection of a methyl group at the 6 position of the pyridine ring in $\mathrm{L}^{3}$ sterically prevents the contraction of the $\mathrm{Fe}-\mathrm{N}$ bonds required for the formation of $\mathrm{Fe}^{\mathrm{II}}{ }_{\text {ls }}$ in $(\mathrm{HHH})$ $\left[\mathrm{LnFe}\left(\mathrm{L}^{3}\right)_{3}\right]^{5+} \cdot{ }^{[10,14]}$ Particular attention has been focused on the thermodynamic properties of these metallosupramolecular assemblies containing poorly coordinating $\mathrm{Fe}^{\mathrm{II}}{ }_{\text {hs }}$, together with a complete characterization of the consequences of intermetallic communications on the magnetic and optical properties of the final complexes.

\section{Results and Discussion}

Synthesis of the ligand $\mathbf{L}^{3}$ : The heterotopic ligand 2-\{6- $(N, N-$ diethylcarbamoyl)pyridin-2-yl\}-1,1'-dimethyl-5,5'-methylene2'-(6-methylpyridine-2-yl)bis[1H-benzimidazole] $\left(\mathrm{L}^{3}\right)$ consists of two distinct benzimidazole-pyridine segments separated by a methylene spacer. The tridentate binding unit possesses an extra carboxamide group bound to the 6 position of the pyridine ring, while a methyl group occupies the symmetryrelated position in the bidentate binding unit. $\mathrm{L}^{3}$ is obtained in three steps from the unsymmetrical synthon $\mathbf{1}$ according to the usual multistep strategy based on a modified Philips reaction for the preparation of benzimidazole rings from the bis-[N-(2nitroarene)-carboxamide] precursor $\mathbf{3}$ (Scheme 2). ${ }^{[2,15,16]}$

Self-assembly processes with $\mathbf{L}^{\mathbf{3}}$ : As previously reported for $\mathrm{L}^{1}$ and $\mathrm{L}^{2}, \mathrm{~L}^{3}$ possesses a tridentate segment coded for the coordination of $\mathrm{Ln}^{\mathrm{III}}$ (two heterocyclic nitrogens and one amide oxygen), while the bidentate segment (two heterocyclic nitrogens) is coded for soft $\mathrm{M}^{\mathrm{II}}$ metal ions. ${ }^{[2,15]}$ This architectural concept selectively and quantitatively produces head-tohead-to-head heterodimetallic triple-stranded helicates $(\mathrm{HHH})-\left[\operatorname{LnM}\left(\mathrm{L}^{i}\right)_{3}\right]^{5+}(i=1,2)$ under stoichiometric conditions both in solution and in the solid state, as demonstrated by the crystal structures of $(\mathrm{HHH})-\left[\operatorname{EuZn}\left(\mathrm{L}^{1}\right)_{3}\right]^{5+},{ }^{[15]}(\mathrm{HHH})-$ $\left[\mathrm{LaFe}\left(\mathrm{L}^{1}\right)_{3}\right]^{5+}$, and $(\mathrm{HHH})-\left[\mathrm{EuZn}\left(\mathrm{L}^{2}\right)_{3}\right]^{5+}$ (Scheme 1). ${ }^{[2]}$ The three ligand strands are wrapped around the helical axis defined by the metals to produce a pseudotricapped trigonalprismatic site for ninefold coordination of $\mathrm{Ln}^{\mathrm{III}}$ and a facial pseudooctahedral site for $\mathrm{M}^{\mathrm{II}}$. We expect that the methyl group bound to the 6 position of the terminal pyridine ring in 


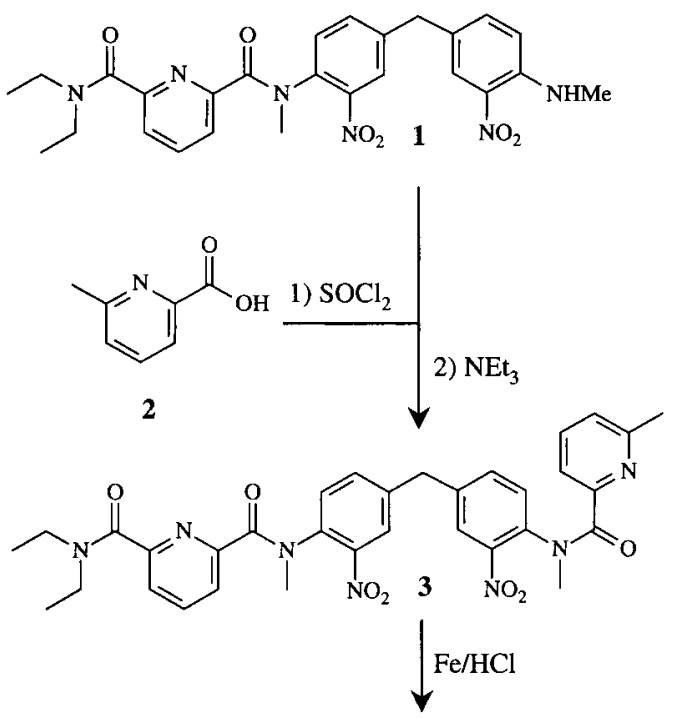

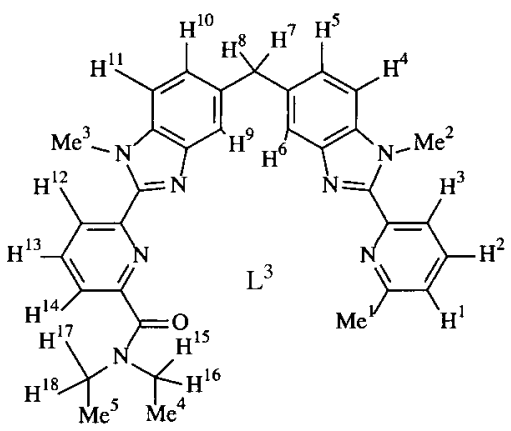

Scheme 2. Synthesis of $\mathrm{L}^{3}$.

$\mathrm{L}^{3}$ produces enough steric bulk in $(\mathrm{HHH})-\left[\mathrm{LnM}\left(\mathrm{L}^{3}\right)_{3}\right]^{5+}$ to force $\mathrm{M}^{\mathrm{II}}=\mathrm{Fe}^{\mathrm{II}}$ to adopt a pure high-spin electronic configuration. However, the associated decrease in stability of the final complexes may severely affect the strict self-assembly process. A complete characterization of the energy hypersurface of the assembly processes involving $\mathrm{L}^{3}$ is thus required and we have used the usual combination ${ }^{[17]}$ of ESI-MS titrations for qualitative speciation, ${ }^{[18]}$ spectrophotometry for the subsequent quantitative analysis, ${ }^{[19]}$ and ${ }^{1} \mathrm{H}$ NMR to investigate solution structures.

Homometallic complexes of $\mathrm{L}^{\mathbf{3}}$ with $\mathrm{La}^{\mathrm{III}}$ and $\mathrm{Zn}^{\mathrm{II}}$ : Titrations of $\mathrm{L}^{3}\left(10^{-4} \mathrm{M}\right.$ in acetonitrile) with $\mathrm{La}\left(\mathrm{ClO}_{4}\right)_{3} \cdot 8 \mathrm{H}_{2} \mathrm{O}$ were followed by spectrophotometry (stoichiometric ratios $\left.\mathrm{La}: \mathrm{L}^{3}=0-2.0\right)$. The absorption spectra display a complicated variation with end points for $\mathrm{La}: \mathrm{L}^{3}=0.3,0.5$, and 0.7 ; this is in contrast with the smooth evolution observed for $\mathrm{L}^{1}$ under the same conditions. ${ }^{[15]}$ The absence of isobestic points suggests the formation of at least three different absorbing species, which is confirmed by factor analysis. ${ }^{[20]}$ The spectrophotometric data can be fitted to the equilibria given in Equations (1) and (2). ${ }^{[21]}$

$$
\begin{aligned}
& \mathrm{La}^{3+}+3 \mathrm{~L}^{3} \rightleftharpoons\left[\mathrm{La}\left(\mathrm{L}^{3}\right)_{3}\right]^{3+}, \quad \log \beta_{13}^{\mathrm{La}}=17.7(3) \\
& 2 \mathrm{La}^{3+}+3 \mathrm{~L}^{3} \rightleftharpoons\left[\mathrm{La}_{2}\left(\mathrm{~L}^{3}\right)_{3}\right]^{6+}, \quad \log \beta_{23}^{\mathrm{La}}=22.9(3)
\end{aligned}
$$

Compared to $\mathrm{L}^{1}$ for which $\log \beta_{13}^{\mathrm{La}}=19.6(5)$ and $\log \beta_{23}^{\mathrm{La}}=$ $27.5(9),{ }^{[15]}$ the stability constants are reduced by two and five orders of magnitude, respectively. However, they are in agreement with those reported for $\mathrm{L}^{2}\left(\log \beta_{13}^{\mathrm{La}}=15.1(4)\right.$ and $\left.\log \beta_{23}^{\mathrm{La}}=20.1(4)\right)^{[2]}$ which possesses a strong electron-withdrawing sulfonamide group bound to the terminal pyridine ring. Variable-temperature ${ }^{1} \mathrm{H}$ NMR titration of $\mathrm{L}^{3}(1.43 \mathrm{mM}$ in $\mathrm{CD}_{3} \mathrm{CN}$ ) by $\mathrm{La}^{\mathrm{III}}$ reveals complicated dynamic processes which are fast enough at $60^{\circ} \mathrm{C}$ to give resolved NMR spectra with 20 signals for $\mathrm{La}: \mathrm{L}^{3}=0.33$ (see Supporting Information; Table S1). Nuclear Overhauser effects (NOEs) observed between $\mathrm{H}^{12}-\mathrm{Me}^{3}$ and $\mathrm{H}^{14}-\mathrm{H}^{17,} 18$ imply a cis - cis conformation of the tridentate binding unit resulting from its threefold coordination to $\mathrm{La}^{\mathrm{III}}$. A related NOE observed between $\mathrm{Me}^{1}-$ $\mathrm{Me}^{2}$ corresponds to a transoid arrangement of the uncoordinated bidentate binding unit as similarly found in $\mathrm{L}^{3}$. We conclude that the three tridentate binding segments are meridionally coordinated to $\mathrm{La}^{\mathrm{III}}$ in $\left[\mathrm{La}\left(\mathrm{L}^{3}\right)_{3}\right]^{3+}$ as similarly reported for $\left[\mathrm{La}\left(\mathrm{L}^{2}\right)_{3}\right]^{3+} \cdot{ }^{[2]}$ However, the enantiotopic character of $\mathrm{H}^{7,8}, \mathrm{H}^{15,16}$, and $\mathrm{H}^{17,18}$ implies a fast interconversion between the facial and meridional conformers and/or between the helical facial enantiomers on the NMR timescale. For $\mathrm{La}: \mathrm{L}^{3}=0.5$, the 20 resolved signals are still observed at $60^{\circ} \mathrm{C}$ but at slightly different chemical shifts compared to those of $\left[\mathrm{La}\left(\mathrm{L}^{3}\right)_{3}\right]^{3+}$. The subsequent addition of metal $\left(\mathrm{La}: \mathrm{L}^{3} \geq 0.66\right)$ results in a significant broadening which prevents further interpretation of the spectra. This probably reflects dynamic exchange processes that involve $\left[\mathrm{La}\left(\mathrm{L}^{3}\right)_{3}\right]^{3+}$ and $\left[\mathrm{La}_{2}\left(\mathrm{~L}^{3}\right)_{3}\right]^{6+}$. For larger $\mathrm{La}: \mathrm{L}^{3}$ ratios $\left(\mathrm{La}: \mathrm{L}^{3} \geq 2: 1\right)$, the quantitative formation of the final complex $\left[\mathrm{La}_{2}\left(\mathrm{~L}^{3}\right)_{3}\right]^{6+}$ leads to 20 resolved signals at room temperature. NOEs between $\mathrm{H}^{12}-\mathrm{Me}^{3}, \mathrm{H}^{14}-$ $\mathrm{H}^{17,18}$ and $\mathrm{H}^{3}-\mathrm{Me}^{2}$ imply the coordination of the two different binding units to $\mathrm{La}^{\mathrm{III}}$ which is compatible with a mixture of (HHH)- $\left[\mathrm{La}_{2}\left(\mathrm{~L}^{3}\right)_{3}\right]^{6+}$ and (HHT)- $\left[\mathrm{La}_{2}\left(\mathrm{~L}^{3}\right)_{3}\right]^{6+}$ exhibiting fast interconversion on the NMR time scale. This behavior strongly contrasts with the successive formation of four complexes with $\mathrm{L}^{1}\left(\left[\mathrm{La}\left(\mathrm{L}^{1}\right)_{3}\right]^{3+},\left[\mathrm{La}_{2}\left(\mathrm{~L}^{1}\right)_{3}\right]^{6+},\left[\mathrm{La}_{2}\left(\mathrm{~L}^{1}\right)_{2}\right]^{6+}\right.$, and $\left.\left[\mathrm{La}_{3}\left(\mathrm{~L}^{1}\right)_{2}\right]^{9+}\right)^{[15]}$ which exist under slow dynamic equilibria on the NMR time scale. This difference can be traced back to the specific connection of the terminal methyl group which significantly reduces the complexing ability of the bidentate unit for $\mathrm{La}^{\mathrm{III}}$ when going from $\mathrm{L}^{1}$ to $\mathrm{L}^{3}$.

Spectrophotometric titrations of $\mathrm{L}^{3}\left(10^{-4} \mathrm{M}\right.$ in acetonitrile) with $\mathrm{Zn}\left(\mathrm{ClO}_{4}\right)_{2} \cdot 7 \mathrm{H}_{2} \mathrm{O}$ suggest that at least three absorbing species are necessary to reproduce the experimental data which can be satisfyingly fitted to the equilibria given in Equations (3) and (4):

$$
\begin{aligned}
& \mathrm{Zn}^{2+}+2 \mathrm{~L}^{3} \rightleftharpoons\left[\mathrm{Zn}\left(\mathrm{L}^{3}\right)_{2}\right]^{2+}, \quad \log \beta_{12}^{\mathrm{Zn}}=12.2(5) \\
& 2 \mathrm{Zn}^{2+}+2 \mathrm{~L}^{3} \rightleftharpoons\left[\mathrm{Zn}_{2}\left(\mathrm{~L}^{3}\right)_{2}\right]^{4+}, \quad \log \beta_{22}^{\mathrm{Zn}}=17.3(5)
\end{aligned}
$$

Previous titrations with $\mathrm{L}^{1}$ under the same conditions led to a different speciation $\left(\left[\mathrm{Zn}\left(\mathrm{L}^{1}\right)_{3}\right]^{2+}, \quad\left[\mathrm{Zn}_{2}\left(\mathrm{~L}^{1}\right)_{3}\right]^{4+}\right.$, and $\left.\left[\mathrm{Zn}_{2}\left(\mathrm{~L}^{1}\right)_{2}\right]^{4+}\right)^{[15]}$ which exemplifies the drastic change occurring in the assembly processes when the methyl group of the terminal pyridine ring is shifted from the 5 position in $\mathrm{L}^{1}$ to the 6 position in $\mathrm{L}^{3}$. Moreover, $\log \beta_{22}^{\mathrm{Zn}}$ is reduced for $\left[\mathrm{Zn}_{2}\left(\mathrm{~L}^{3}\right)_{2}\right]^{4+}$ by four orders of magnitude. This indicates that the bidentate binding unit of $\mathrm{L}^{3}$ also displays poor coordinating properties for d-block ions. Variable-temperature ${ }^{1} \mathrm{H}$ NMR titrations at a 
higher concentration $\left(12 \mathrm{~mm}\right.$ in $\mathrm{CD}_{3} \mathrm{CN}$ ) reveal a complicated behavior involving dynamic processes. For $\mathrm{Zn}^{\mathrm{II}}: \mathrm{L}^{3}=1: 2$, chemical exchanges at $-40^{\circ} \mathrm{C}$ are slow enough to give a well-resolved spectrum with 46 signals that correspond to two nonequivalent ligands. The diastereotopic characters of $\mathrm{H}^{7,8}$, $\mathrm{H}^{15,16}$, and $\mathrm{H}^{17,18}$ show the chirality of $\left[\mathrm{Zn}\left(\mathrm{L}^{3}\right)_{2}\right]^{2+}$ in agreement with a $\mathrm{Zn}^{\mathrm{II}}$ ion pentacoordinated by one bidentate and one tridentate unit of each ligand. For $\mathrm{Zn}^{\mathrm{II}}: \mathrm{L}^{3} \geq 1.0$, 24 wellresolved signals are observed and a detailed analysis establishes that (HT)- $\left[\mathrm{Zn}_{2}\left(\mathrm{~L}^{3}\right)_{2}\right]^{4+}$ adopts a $C_{2}$-symmetrical headto-tail double-helical structure, very similar to that reported for $\left[\mathrm{Zn}_{2}\left(\mathrm{~L}^{1}\right)_{2}\right]^{4+}$ (interstrand NOEs observed between $\mathrm{Me}^{1}$ and $\mathrm{Me}^{4}$, see Supporting Information, Table S1). ${ }^{[15]}$

Heterodimetallic complexes of $\mathrm{L}^{3}$ with $\mathrm{La}^{\mathrm{III}}$ and $\mathrm{M}^{\mathrm{II}}(\mathrm{M}=\mathrm{Zn}$, Fe): ESI-MS titrations of $\mathrm{L}^{3}\left(10^{-4} \mathrm{M}\right.$ in acetonitrile) with an equimolar mixture of $\mathrm{La}\left(\mathrm{ClO}_{4}\right)_{3} \cdot 8 \mathrm{H}_{2} \mathrm{O}$ and $\mathrm{M}\left(\mathrm{ClO}_{4}\right)_{2} \cdot 6 \mathrm{H}_{2} \mathrm{O}$ $(\mathrm{M}=\mathrm{Zn}, \mathrm{Fe})$ show the formation of the heterodimetallic species $\left[\mathrm{LaM}\left(\mathrm{L}^{3}\right)_{3}\right]^{5+}$, together with significant signals corresponding to homometallic d-block complexes $\left[\mathrm{M}_{(}\left(\mathrm{L}^{3}\right)_{3}\right]^{2+}$, $\left[\mathrm{M}\left(\mathrm{L}^{3}\right)_{2}\right]^{2+}, \quad$ and $\quad\left[\mathrm{M}_{2}\left(\mathrm{~L}^{3}\right)_{2}\right]^{4+}$ $(\mathrm{M}=\mathrm{Zn}$, Fe, see Supporting Information, Table S2). For the $\mathrm{Zn}^{\mathrm{II}} / \mathrm{La}^{\mathrm{III}}$ system, spectrophotometric titrations under similar conditions and for metal: $\mathrm{L}^{3}=$ $0-2.0$ (metal concentration $=$ Ln concentration $=\mathrm{Zn}$ concentration) display complicated variations with no sharp endpoint. This is in agreement with several absorbing species, as suggested by ESI-MS data. The great similitude between the reconstructed UV spectra prevents the determination of the stability constants, but ${ }^{1} \mathrm{H}$ NMR titrations show the quantitative formation of the heterodimetallic complex $(\mathrm{HHH})-\left[\mathrm{LaZn}\left(\mathrm{L}^{3}\right)_{3}\right]^{5+} \quad$ for $\mathrm{La}^{\mathrm{III}}: \mathrm{Zn}^{\mathrm{II}}: \mathrm{L}^{3}=1: 1: 3$ and total ligand concentrations greater than $10 \mathrm{~mm}$. The ${ }^{1} \mathrm{H}$ NMR spectra of $(\mathrm{HHH})-\left[\mathrm{LnZn}\left(\mathrm{L}^{3}\right)_{3}\right]^{5+}$ $(\mathrm{Ln}=\mathrm{La}, \mathrm{Eu})$ display 23 signals corresponding to three equivalent ligands on the NMR timescale. Intrastrand $\left(\mathrm{H}^{3}-\mathrm{Me}^{2}\right.$, $\left.\mathrm{H}^{12}-\mathrm{Me}^{3}, \mathrm{H}^{17,18}-\mathrm{H}^{14}\right)$ and interstrand $\left(\mathrm{H}^{5}-\mathrm{Me}^{3}, \mathrm{H}^{4}-\mathrm{Me}^{3}\right.$, $\mathrm{H}^{10}-\mathrm{Me}^{2}$, and $\left.\mathrm{H}^{11}-\mathrm{Me}^{2}\right)$ NOEs associated with 1) large upfield shields for $\mathrm{H}^{6} \quad(\Delta \delta=$ $-2.30 \mathrm{ppm})$ and $\mathrm{H}^{9} \quad(\Delta \delta=$ $-1.88 \mathrm{ppm})$ occurring upon complexation in (HHH)-[LaZn$\left.\left(\mathrm{L}^{3}\right)_{3}\right]^{5+}$ and 2) diastereotopic characters for $\mathrm{H}^{7,8}, \mathrm{H}^{15,16}$, and $\mathrm{H}^{17,18}$, are diagnostic for the formation of the head-to-head-to-head $C_{3}$-symmetrical triplehelical complexes $(\mathrm{HHH})-\left[\mathrm{LnZn}\left(\mathrm{L}^{3}\right)_{3}\right]^{5+}$ in which $\mathrm{Zn}^{\mathrm{II}}$ is pseudooctahedrally coordinated by the three bidentate binding units and ninefold coordination of $\mathrm{Ln}^{\mathrm{III}}$ in a pseudotricapped trigonal-prismatic environment (Scheme 1, Figure 1). ${ }^{[2,15]}$ However, for metal: $\mathrm{L}^{3} \geq 0.33$, the heterodimetallic complex is progressively replaced by $(\mathrm{HT})-\left[\mathrm{Zn}_{2}\left(\mathrm{~L}^{3}\right)_{2}\right]^{4+}$ which strongly contrasts with the behavior of $\mathrm{L}^{1}$ for which $(\mathrm{HHH})$ $\left[\mathrm{LnZn}\left(\mathrm{L}^{1}\right)_{3}\right]^{5+}$ complexes remain intact in the presence of excess $\mathrm{Zn}^{\mathrm{II}} .^{[15]}$ Moreover, the dilution of a concentrated solution of $(\mathrm{HHH})-\left[\mathrm{LaZn}\left(\mathrm{L}^{3}\right)_{3}\right]^{5+}$ in acetonitrile shows the appearance of detectable amounts of homometallic complexes $(>3 \%)$ for a total ligand concentration smaller than $7 \mathrm{~mm}$. This confirms the weaker stability of the heterodimetallic complex $(\mathrm{HHH})-\left[\mathrm{LaZn}\left(\mathrm{L}^{3}\right)_{3}\right]^{5+}$ compared to (HHH)$\left[\mathrm{LaZn}\left(\mathrm{L}^{1}\right)_{3}\right]^{5+} \cdot{ }^{[15]}$ We conclude that the sterically constrained bidentate binding unit in $\mathrm{L}^{3}$ severely limits the coordination possibilities of the bidentate segment and the quantitative

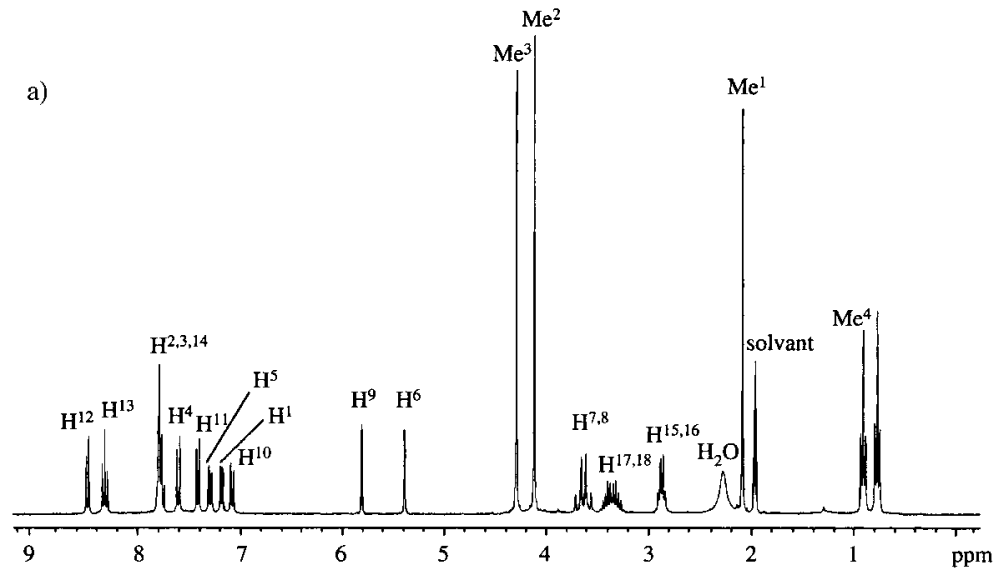

b)
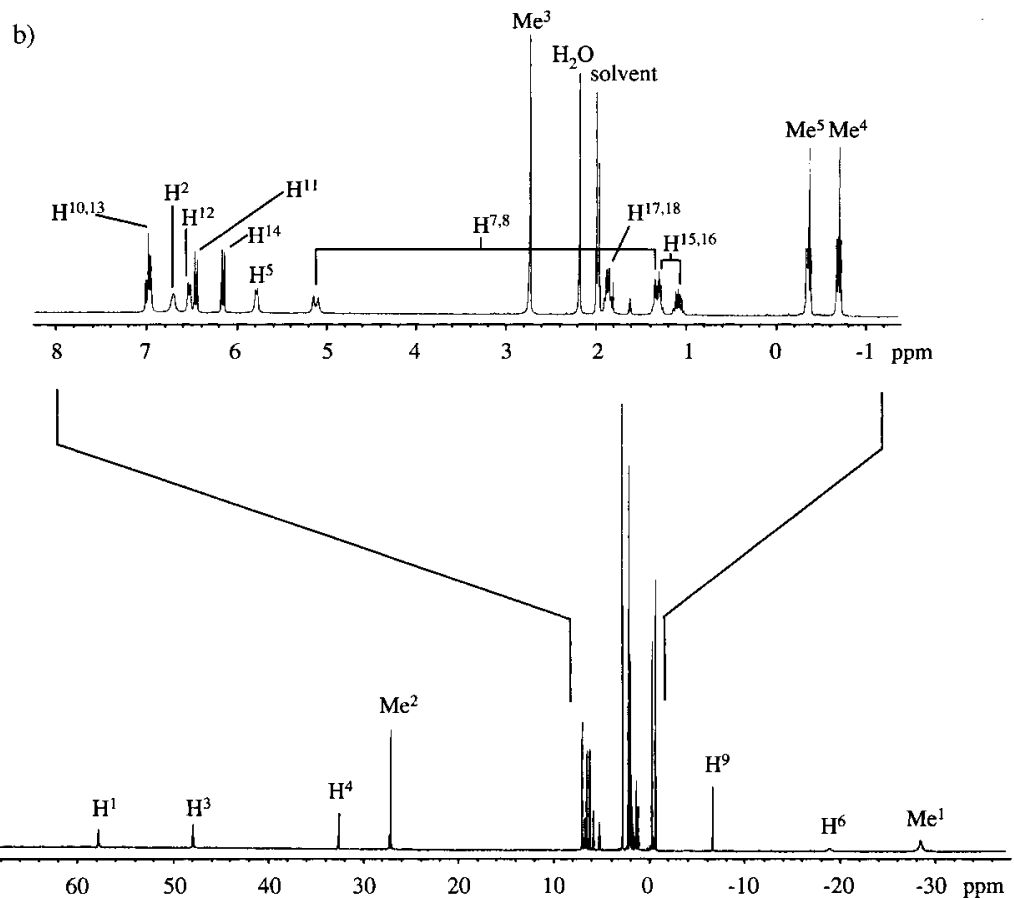

Figure 1. ${ }^{1} \mathrm{H}$ NMR spectra of a) $(\mathrm{HHH})-\left[\mathrm{LaZn}\left(\mathrm{L}^{3}\right)_{3}\right]^{5+}$ and b) $(\mathrm{HHH})-\left[\mathrm{LaFe}\left(\mathrm{L}^{3}\right)_{3}\right]^{5+}$ in $\mathrm{CD}_{3} \mathrm{CN}(298 \mathrm{~K})$. 
formation of the head-to-head-to-head complexes (HHH)$\left[\mathrm{LnZn}\left(\mathrm{L}^{3}\right)_{3}\right]^{5+}$ requires strict stoichiometric conditions and a total ligand concentration greater than $10 \mathrm{~mm}$.

Surprisingly, spectrophotometric titrations of $\mathrm{L}^{3}\left(10^{-4} \mathrm{M}\right.$ in acetonitrile) with an equimolar mixture of $\mathrm{La}\left(\mathrm{ClO}_{4}\right)_{3} \cdot 8 \mathrm{H}_{2} \mathrm{O}$ and $\mathrm{Fe}\left(\mathrm{ClO}_{4}\right)_{2} \cdot 6 \mathrm{H}_{2} \mathrm{O}$ display a sharp end-point for a metal to $\mathrm{L}^{3}$ ratio of 0.33 . This suggests that the heterodimetallic complex (HHH)-[LaFe $\left.\left(\mathrm{L}^{3}\right)_{3}\right]^{5+}$ is selectively produced in solution which contrasts with the intricate mixtures observed for similar titrations performed with $\mathrm{La}^{\mathrm{III}} / \mathrm{Zn}^{\mathrm{II}}$ (Figure 2). The
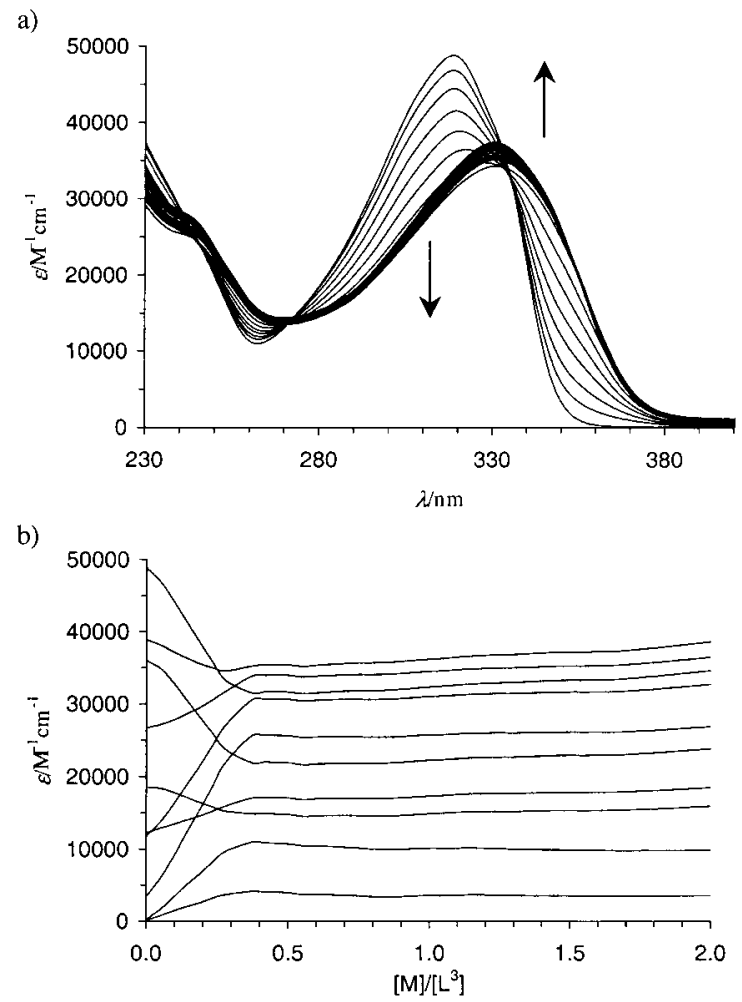

Figure 2. a) Variation of absorption spectra observed for the spectrophotometric titration of $\mathrm{L}^{3}\left(10^{-4} \mathrm{M}\right.$ in acetonitrile) with an equimolar mixture of $\mathrm{La}\left(\mathrm{ClO}_{4}\right)_{2} \cdot 8 \mathrm{H}_{2} \mathrm{O}$ and $\mathrm{Fe}\left(\mathrm{ClO}_{4}\right)_{2} \cdot 6 \mathrm{H}_{2} \mathrm{O}$ at $293 \mathrm{~K}$. b) Corresponding variation of observed molar extinctions at 10 different wavelengths $([\mathrm{M}]=$ concentration $\mathrm{La}=$ concentration $\mathrm{Fe})$.

great similitude between the reconstructed UV spectra again prevents a reliable determination of stability constants and we suspect that the selective formation of $(\mathrm{HHH})-\left[\mathrm{LaFe}\left(\mathrm{L}^{3}\right)_{3}\right]^{5+}$ mainly results from a decrease in the stability of the competitive $\mathrm{Fe}^{\mathrm{II}}$ homometallic species in solution. ${ }^{1} \mathrm{H}$ NMR titrations confirm that $(\mathrm{HHH})-\left[\mathrm{LaFe}\left(\mathrm{L}^{3}\right)_{3}\right]^{5+}$ is the only significant species in solution for $\mathrm{Ln}: \mathrm{Fe}: \mathrm{L}^{3}=1: 1: 3$ and a total ligand concentration greater than $3 \times 10^{-4} \mathrm{M}$. As similarly found for $(\mathrm{HHH})-\left[\mathrm{LnZn}\left(\mathrm{L}^{3}\right)_{3}\right]^{5+}$, the ${ }^{1} \mathrm{H}$ NMR spectra of the paramagnetic complexes $(\mathrm{HHH})-\left[\mathrm{LnFe}\left(\mathrm{L}^{3}\right)_{3}\right]^{5+}(\mathrm{Ln}=\mathrm{La}, \mathrm{Eu})$ display 23 signals, but spread over $90 \mathrm{ppm}$ as a result of the paramagnetic shifts induced by the rapidly relaxing pseudooctahedral high-spin $\mathrm{Fe}^{\mathrm{II}}$ (see Supporting Information, Table S1; Figure 1).[22] The slightly broadened NMR signals of the tridentate binding unit were assigned by means of twodimensional correlation $\left\{{ }^{1} \mathrm{H}-{ }^{1} \mathrm{H}\right\}-\mathrm{COSY}$ spectra and NOE measurements, while the broad signals observed for the protons of the bidentate binding unit (which are close to $\mathrm{Fe}^{\mathrm{II}}{ }_{\text {hs }}$ ) were assigned by comparison with the temperature dependence of related signals in the spin-crossover complexes (HHH)-[LnFe $\left.\left.\left(\mathrm{L}^{2}\right)_{3}\right]^{5+} .{ }^{52}\right]$ We conclude from detailed NMR analyses at variable temperature that 1) $\mathrm{Fe}^{\mathrm{II}}$ remains high-spin in the temperature range $233-333 \mathrm{~K}$ and 2) (HHH)$\left[\mathrm{LnFe}\left(\mathrm{L}^{2}\right)_{3}\right]^{5+}$ adopts the expected $C_{3}$-symmetrical triplehelical structure in which a pseudooctahedral $\mathrm{Fe}^{\mathrm{II}}$ ion occupies the noncovalent tripod defined by the three coordinated bidentate binding units (Scheme 1). As expected from the ligand design, the presence of a methyl group close to $\mathrm{Fe}^{\mathrm{II}}$ prevents the contraction of the $\mathrm{Fe}-\mathrm{N}$ bond required for lowspin configuration, thus leading to the formation of pure highspin complexes $(\mathrm{HHH})-\left[\mathrm{LnFe}\left(\mathrm{L}^{3}\right)_{3}\right]^{5+}$ in solution.

Slow diffusion of diethyl ether into concentrated acetonitrile solutions of $(\mathrm{HHH})-\left[\mathrm{LnM}\left(\mathrm{L}^{3}\right)_{3}\right]^{5+}$ produces white $(\mathrm{M}=$ $\mathrm{Zn})$ or yellow $(\mathrm{M}=\mathrm{Fe})$ microcrystalline powders, whose elemental analyses are compatible with the formula $\left[\mathrm{LnZn}\left(\mathrm{L}^{3}\right)_{3}\right]\left(\mathrm{ClO}_{4}\right)_{5} \cdot \mathrm{H}_{2} \mathrm{O} \quad(\mathrm{Ln}=\mathrm{La}, \quad 4 ; \mathrm{Eu}, \quad 5)$ and $\left[\mathrm{LnFe}\left(\mathrm{L}^{3}\right)_{3}\right]\left(\mathrm{ClO}_{4}\right)_{5} \cdot n \mathrm{H}_{2} \mathrm{O} \cdot x \mathrm{MeCN}(\mathrm{Ln}=\mathrm{La}, n=2, x=1.5$ : 6; $\mathrm{Ln}=\mathrm{Eu}, n=1, x=0: 7 ; \mathrm{Ln}=\mathrm{Gd}: \mathrm{Eu}(98: 2), n=2, x=0: 8)$. Their IR spectra show the bands characteristic of the coordinated ligands $\left(v_{\mathrm{C}=\mathrm{O}}\right.$ and $v_{\mathrm{C}=\mathrm{N}}$ in the $1600-1450 \mathrm{~cm}^{-1}$ range), ${ }^{[2,15]}$ together with vibrations typical of ionic perchlorates $\left(625\right.$ and $\left.1100 \mathrm{~cm}^{-1}\right) \cdot{ }^{[23]}$ All attempts to obtain crystals suitable for X-ray diffraction were unsuccessful.

Magnetic and electrochemical properties of $\left[\mathrm{LaFe}\left(\mathrm{L}^{3}\right)_{3}\right]-$ $\left(\mathrm{ClO}_{4}\right)_{5} \cdot \mathbf{2} \mathrm{H}_{2} \mathrm{O} \cdot 1.5 \mathrm{MeCN}(\mathbf{6})$ : The thermal dependence $(2-$ $300 \mathrm{~K})$ of the magnetic moment, expressed as $\chi T$, is complicated: $\chi T=3.26 \mathrm{~cm}^{3} \mathrm{~K} \mathrm{~mol}^{-1}$ at $300 \mathrm{~K}$ slightly increases to give a maximum at $70 \mathrm{~K}\left(\chi T=3.74 \mathrm{~cm}^{3} \mathrm{~K} \mathrm{~mol}^{-1}\right)$ followed by an abrupt decrease at lower temperature to reach $\chi T=$ $2.40 \mathrm{~cm}^{3} \mathrm{~K} \mathrm{~mol}^{-1}$ at $2 \mathrm{~K}$ (Figure 3 ). This magnetic behavior is
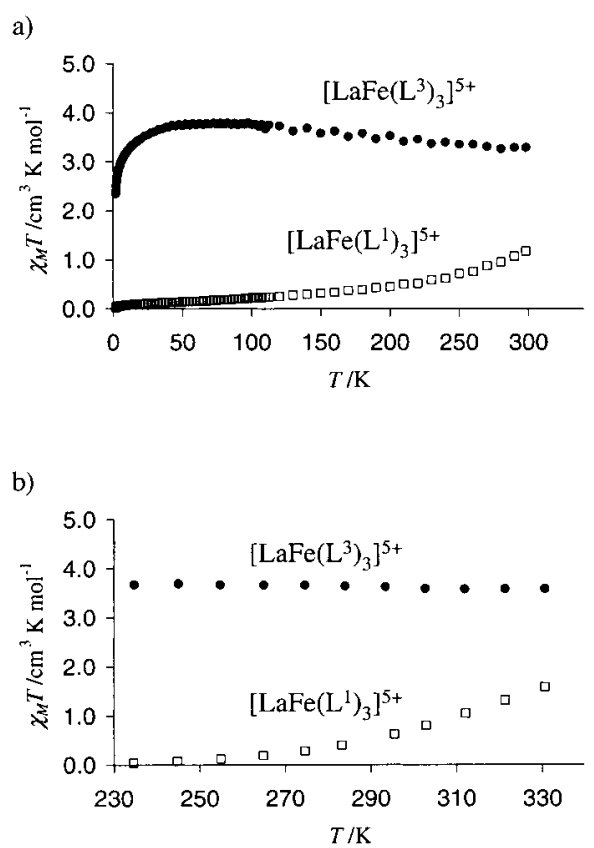

Figure 3. $\chi_{\mathrm{M}} T$ as a function of temperature for $(\mathrm{HHH})-\left[\mathrm{LaFe}\left(\mathrm{L}^{\mathrm{i}}\right)_{3}\right]^{5+}(i=1$, 3). a) In the solid state and b) in acetonitrile. 
typical of a pseudooctahedral pure high-spin $\mathrm{Fe}^{\mathrm{II}}(S=2)$. The slight increase between $300-70 \mathrm{~K}$ can be rationalized by the classical Kotani curves which consider spin-orbit coupling, ${ }^{[24]}$ while the decrease at low temperature arises from zero-field splitting. ${ }^{[25]}$ A nonlinear least-squares fit of the data, including the magnetic susceptibility contributions for zero-field splitting of a spin multiplet $(S=2 \text {, isotropic solids })^{[26]}$ for pseudooctahedral high-spin $\mathrm{d}^{6}$ ion, yields a $g$ value of 2.18 and a zero-field parameter $|D|=4.2 \mathrm{~cm}^{-1}$. These results are in good agreement with similar treatments applied to the related pseudooctahedral high-spin complexes [Fe(4,6-bisphenylterpy $\left.)_{2}\right]\left(\mathrm{PF}_{6}\right)_{2}\left(g=2.16,|D|=7.9 \mathrm{~cm}^{-1}\right)^{[27]}$ and $\left[\mathrm{Fe}\left(\mathrm{H}_{2}\right.\right.$ sarcophagine $) \mathrm{Cl}_{2} \mathrm{Br}_{2}\left(g=2.2,|D|=6.8 \mathrm{~cm}^{-1}\right) .{ }^{[28]}$ Dissolution of 6 in acetonitrile gives an NMR spectrum identical to that obtained for $(\mathrm{HHH})-\left[\mathrm{LaFe}\left(\mathrm{L}^{3}\right)_{3}\right]^{5+}$ during titration processes (see above). Values of $\chi T$ were determined in the temperature range $233-333 \mathrm{~K}$ by the Evans' method, ${ }^{[29]}$ with diamagnetic correction. ${ }^{[30]}$ The molar magnetic susceptibility within this short temperature range shows a Curie-type behavior, with $\chi T=3.6(5) \mathrm{cm}^{3} \mathrm{~K} \mathrm{~mol}^{-1} \quad$ (correlation coefficient $\left.=0.9919\right)$. This is in complete agreement with 1) a pure high-spin electronic configuration of the $\mathrm{Fe}^{\mathrm{II}}$ ion $(S=2)$ and 2) previous fits of the thermal spin-crossover processes occurring in $(\mathrm{HHH})-\left[\mathrm{LnFe}\left(\mathrm{L}^{1}\right)_{3}\right]^{5+}$ which led to estimated values of $\chi T=$ $3.6(2) \mathrm{cm}^{3} \mathrm{~K} \mathrm{~mol}^{-1}$ for the high-spin form. ${ }^{[2]}$ These magnetic measurements demonstrate that pseudooctahedral $\mathrm{Fe}^{\mathrm{II}}$ in $(\mathrm{HHH})-\left[\mathrm{LaFe}\left(\mathrm{L}^{3}\right)_{3}\right]^{5+}$ adopts a pure high-spin electronic configuration $(S=2)$ in the solid state $(2-300 \mathrm{~K})$ and in acetonitrile, in contrast with the room-temperature spincrossover behavior previously established for the analogous complex (HHH)- $\left[\mathrm{LnFe}\left(\mathrm{L}^{1}\right)_{3}\right]^{5+}$. In $(\mathrm{HHH})-\left[\mathrm{LaFe}\left(\mathrm{L}^{3}\right)_{3}\right]^{5+}$, the steric constraints induced by the terminal methyl groups of $\mathrm{L}^{3}$ prevent the contraction of the $\mathrm{Fe}-\mathrm{N}$ bonds required for the low-spin configuration, as similarly proposed for a substituted terpyridine in the high-spin complex $[\mathrm{Fe}(4,6$-bisphenylterpy $\left.)_{2}\right]\left(\mathrm{PF}_{6}\right)_{2}{ }^{[27]}$ and for 6-methylpyridine-benzimidazole units in the dimetallic triple-stranded helicate $\left[\mathrm{Fe}_{2}(\mathrm{~L})_{3}\right]^{4+} \cdot{ }^{[10]}$

In contrast to $(\mathrm{HHH})-\left[\mathrm{LnFe}\left(\mathrm{L}^{1}\right)_{3}\right]^{5+}$ complexes which display a reversible $\mathrm{Fe}^{\mathrm{II}} / \mathrm{Fe}^{\mathrm{III}}$ oxidation wave $\left(E_{1 / 2}^{\text {red }}=0.82 \mathrm{~V}\right.$ vs. $\mathrm{SCE}$ in $\left.\mathrm{MeCN}+0.1 \mathrm{M} \mathrm{NBu} \mathrm{PF}_{6}\right),{ }^{[2]}$ no wave corresponding to the oxidation of $\mathrm{Fe}^{\mathrm{II}}$ is observed for $(\mathrm{HHH})-\left[\mathrm{LaFe}\left(\mathrm{L}^{3}\right)_{3}\right]^{5+}$ in the accessible polarization domain of the solvent. Two quasireversible reduction waves, attributed to ligand-centered processes, are observed at $E_{1 / 2}=-1.16 \mathrm{~V}$ and $-1.41 \mathrm{~V}$ versus $\mathrm{SCE}\left(\mathrm{MeCN}+0.1 \mathrm{M} \mathrm{NBu} \mathrm{PF}_{6}\right)$. The destabilization of $\mathrm{Fe}^{\mathrm{III}}$ parallels that of $\mathrm{Fe}^{\mathrm{II}}{ }_{\mathrm{ls}}$ in $(\mathrm{HHH})-\left[\mathrm{LaFe}\left(\mathrm{L}^{3}\right)_{3}\right]^{5+}$ and results from the steric constraints induced by the terminal methyl groups which preclude the contraction of the $\mathrm{Fe}-\mathrm{N}$ bonds required by the oxidation process. ${ }^{[14,27]}$

Photophysical properties of $\left[\operatorname{LnZn}\left(\mathrm{L}^{3}\right)_{3}\right]\left(\mathrm{ClO}_{4}\right)_{5} \cdot \mathrm{H}_{2} \mathrm{O}$ and $\left[\mathbf{L n F e}\left(\mathrm{L}^{3}\right)_{3}\right]\left(\mathrm{ClO}_{4}\right)_{5} \cdot \boldsymbol{n} \mathrm{H}_{2} \mathrm{O} \cdot \boldsymbol{x} \mathrm{MeCN}$ : The reflectance spectrum of $\mathrm{L}^{3}$ displays a broad band centered at $30670 \mathrm{~cm}^{-1}$ (Table 1) and assigned to the envelope of the $\pi \rightarrow \pi^{*}$ transitions. This band is slightly red-shifted upon complexation to $\mathrm{Ln}^{\mathrm{III}}$ and $\mathrm{M}^{\mathrm{II}}$, with the appearance of a weak shoulder at $\approx 27500 \mathrm{~cm}^{-1}$. A supplementary weak and broad band at $\approx 22500 \mathrm{~cm}^{-1}$, observed for the iron complexes $6-\mathbf{8}$, may be assigned to the $\mathrm{Fe}^{\mathrm{II}}{ }_{\text {hs }} \rightarrow \pi^{*}$ MLCT transition. ${ }^{[10]}$ Excitation of the $\pi \rightarrow \pi^{*}$ band of $L^{3}$ at $77 \mathrm{~K}$ provides the expected fluorescence of the ${ }^{1} \pi \pi^{*}$ state (0-phonon transition: $26400 \mathrm{~cm}^{-1}$, vibronic progression: $\left.1150 \mathrm{~cm}^{-1}\right)$ together with the weak, but well-structured phosphorescence bands originating from the ${ }^{3} \pi \pi^{*}$ state (0-phonon transition: $21260 \mathrm{~cm}^{-1}$, vibronic progression: $1570 \mathrm{~cm}^{-1}$, biexponential decay: $\tau=$ $605 \mathrm{~ms}$ and $45 \mathrm{~ms}$ at $13 \mathrm{~K}$, Table 1 ) as similarly reported for $\mathrm{L}^{1}\left({ }^{1} \pi \pi^{*}: 24900 \mathrm{~cm}^{-1},{ }^{3} \pi \pi^{*}\right.$ states: $20040 \mathrm{~cm}^{-1}(\tau=560 \mathrm{~ms}$ and $41 \mathrm{~ms}$ at $10 \mathrm{~K})) \cdot{ }^{[15]}$ The energy of the emitting ${ }^{1} \pi \pi^{*}$ state is red-shifted by $1550 \mathrm{~cm}^{-1}$ in $\left[\mathrm{LaZn}\left(\mathrm{L}^{3}\right)_{3}\right]\left(\mathrm{ClO}_{4}\right)_{5} \cdot \mathrm{H}_{2} \mathrm{O}(4)$, but the emission of the ${ }^{3} \pi \pi$ state is similar to that observed for $\mathrm{L}^{3}$ (20920 $\mathrm{cm}^{-1}$, vibronic progression: $1390 \mathrm{~cm}^{-1}$ ) with a reduced lifetime of $221 \mathrm{~ms}$. For $\left[\mathrm{LaFe}\left(\mathrm{L}^{3}\right)_{3}\right]\left(\mathrm{ClO}_{4}\right)_{5} \cdot 2 \mathrm{H}_{2} \mathrm{O} \cdot 1.5 \mathrm{CH}_{3} \mathrm{CN}$ (6), a very weak ${ }^{3} \pi \pi^{*}$ emission centered at $18870 \mathrm{~cm}^{-1}$ can be detected (biexponential decay: $\tau=261 \mathrm{~ms}$ and $30 \mathrm{~ms}$ at $13 \mathrm{~K})$.

The ligand-centered luminescence in $\left[\mathrm{EuZn}\left(\mathrm{L}^{3}\right)_{3}\right]\left(\mathrm{ClO}_{4}\right)_{5}$. $\mathrm{H}_{2} \mathrm{O}(5)$ is quenched by efficient $\mathrm{L}^{3} \rightarrow \mathrm{Eu}^{\mathrm{III}}$ energy-transfer processes, while excitation via the $\pi \rightarrow \pi^{*}$ transitions produces only the Eu-centered red luminescence characterized by sharp bands associated with ${ }^{5} \mathrm{D}_{0} \rightarrow{ }^{7} \mathrm{~F}_{\mathrm{j}}(j=0-4)$ transitions (Figure 4). The presence of a single and symmetrical ${ }^{5} \mathrm{D}_{0} \leftrightarrow{ }^{7} \mathrm{~F}_{0}$ transition in the emission $\left(17221 \mathrm{~cm}^{-1}\right.$, full width at half height $(\mathrm{fwhh})=16 \mathrm{~cm}^{-1}$ ) and excitation spectra at $13 \mathrm{~K}$ $\left(17221 \mathrm{~cm}^{-1}\right.$, fwhh $\left.=10.7 \mathrm{~cm}^{-1}, \tilde{v}_{\text {an }}=16129 \mathrm{~cm}^{-1}\right)$ points to a unique $\mathrm{Eu}^{\mathrm{III}}$ site. A detailed analysis (see Supporting Information, Table S3) of the multiplicity of the ${ }^{5} \mathrm{D}_{0} \rightarrow{ }^{7} \mathrm{~F}_{\mathrm{j}}(j=1-4)$

Table 1. Ligand-centered absorption and emission properties for the ligands $\mathrm{L}^{i}$ and their complexes $\left[\mathrm{LnM}\left(\mathrm{L}^{i}\right)_{3}\right]^{5+}(i=1,3)$ in the solid state. ${ }^{[a]}$

\begin{tabular}{|c|c|c|c|c|c|c|c|c|c|c|c|}
\hline \multirow{2}{*}{$\frac{\text { Compound }}{\mathrm{L}^{1[\mathrm{~b}]}}$} & \multicolumn{3}{|c|}{$E\left(\pi \rightarrow \pi^{*}\right)\left[\mathrm{cm}^{-1}\right]$} & \multicolumn{3}{|c|}{$E\left({ }^{1} \pi \pi^{*}\right)\left[\mathrm{cm}^{-1}\right]$} & \multicolumn{3}{|c|}{$E\left({ }^{3} \pi \pi^{*}\right)\left[\mathrm{cm}^{-1}\right]$} & \multicolumn{2}{|c|}{$\tau\left({ }^{3} \pi \pi^{*}\right)[\mathrm{ms}]$} \\
\hline & & 30770 & & & 24940 & & 20040 & 18870 & $17860(\mathrm{sh})$ & $560 \pm 18$ & $41 \pm 2$ \\
\hline $\mathrm{L}^{3}$ & & 30670 & & $26400(\mathrm{sh})$ & 25250 & $24100(\mathrm{sh})$ & 21260 & 19690 & $\begin{array}{l}18120 \\
16550\end{array}$ & $605 \pm 15$ & $45 \pm 4$ \\
\hline$\left[\operatorname{LaZn}\left(\mathrm{L}^{1}\right)_{3}\right]^{5+[\mathrm{b}]}$ & & 31000 & & & 22600 & & 19960 & 19050 & $18000(\mathrm{sh})$ & $250 \pm 4$ & $36 \pm 6$ \\
\hline$\left[\operatorname{LaZn}\left(\mathrm{L}^{3}\right)_{3}\right]^{5+}$ & & 30210 & $27470(\mathrm{sh})$ & $24850(\mathrm{sh})$ & 23700 & $22750(\mathrm{sh})$ & 20920 & 19530 & $\begin{array}{l}18140 \\
16750\end{array}$ & $221 \pm 4$ & \\
\hline$\left[\mathrm{EuZn}\left(\mathrm{L}^{1}\right)_{3}\right]^{5+[\mathrm{b}]}$ & $32750(\mathrm{sh})$ & 30900 & $26000(\mathrm{sh})$ & & 21480 & & & {[} & & [c] & \\
\hline$\left[\mathrm{LaFe}\left(\mathrm{L}^{3}\right)_{3}\right]^{5+}$ & 30210 & $27780(\mathrm{sh})$ & $22730(\mathrm{sh})$ & & & & & $18870^{[}$ & & $261 \pm 8$ & $30 \pm 2$ \\
\hline$\left[\mathrm{EuFe}\left(\mathrm{L}^{3}\right)_{3}\right]^{5+}$ & 30670 & $27030(\mathrm{sh})$ & $22220(\mathrm{sh})$ & & & & & & & & \\
\hline$\left[\mathrm{GdFe}\left(\mathrm{L}^{3}\right)_{3}\right]^{5+}($ doped $2 \% \mathrm{Eu})$ & 30580 & $27860(\mathrm{sh})$ & $22370(\mathrm{sh})$ & & & & & & & $376 \pm 98$ & $50 \pm 22$ \\
\hline
\end{tabular}

[a] Reflectance spectra recorded at $295 \mathrm{~K}$, luminescence data at $77 \mathrm{~K}$, and lifetime measurements at $13 \mathrm{~K}$; sh = shoulder. [b] Taken from reference [15]. $[\mathrm{c}]^{3} \pi \pi^{*}$ luminescence quenched by transfer to $\mathrm{Eu}^{\mathrm{III}}$ ion. [d] Very low intensity. 


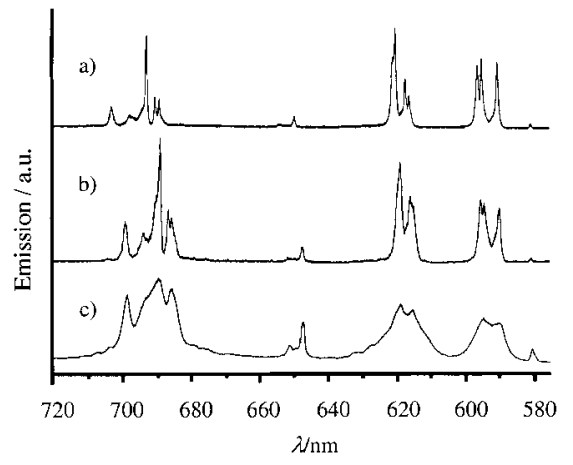

Figure 4. Emission spectra of $(\mathrm{HHH})-\left[\operatorname{EuM}\left(\mathrm{L}^{3}\right)_{3}\right]^{5+}$ in the solid state recorded upon excitation of the ligand-centered ${ }^{1} \pi \pi^{*}$ levels: a) [Eu$\left.\mathrm{Zn}\left(\mathrm{L}^{3}\right)_{3}\right]\left(\mathrm{ClO}_{4}\right)_{5} \cdot \mathrm{H}_{2} \mathrm{O} \quad(5)$ at $13 \mathrm{~K} \quad\left(\lambda_{\text {exc }}=26455 \mathrm{~cm}^{-1}\right)$, b) $\left[\mathrm{EuFe}\left(\mathrm{L}^{3}\right)_{3}\right]-$ $\left(\mathrm{ClO}_{4}\right)_{5} \cdot \mathrm{H}_{2} \mathrm{O}(7)$ at $13 \mathrm{~K}\left(\lambda_{\text {exc }}=32468 \mathrm{~cm}^{-1}\right)$, and c) $\left[\mathrm{EuFe}\left(\mathrm{L}^{3}\right)_{3}\right]\left(\mathrm{ClO}_{4}\right)_{5}$. $\mathrm{H}_{2} \mathrm{O}(7)$ at $295 \mathrm{~K}\left(\lambda_{\text {exc }}=32468 \mathrm{~cm}^{-1}\right)$.

transitions in the laser-excited emission spectrum confirms the pseudotrigonal symmetry for the $\mathrm{Eu}^{\mathrm{III}}$ site (splitting of ${ }^{7} \mathrm{~F}_{1}$ into two main sublevels: $\mathrm{A} \rightarrow \mathrm{A}$ and $\mathrm{A} \rightarrow \mathrm{E}$ separated by $129 \mathrm{~cm}^{-1}$, the latter transition being further split by $35 \mathrm{~cm}^{-1}$; splitting of ${ }^{7} \mathrm{~F}_{4}$ into two $\mathrm{A} \rightarrow \mathrm{E}$ and one $\mathrm{A} \rightarrow \mathrm{A}$ sublevels, Figure $4 \mathrm{a}$ ) which is almost identical to that reported previously for $(\mathrm{HHH})-\left[\mathrm{EuZn}\left(\mathrm{L}^{1}\right)_{3}\right]^{5+} \cdot{ }^{[15]}$ At $295 \mathrm{~K}$, the ${ }^{5} \mathrm{D}_{0} \leftarrow{ }^{7} \mathrm{~F}_{0}$ transition is shifted to $17232 \mathrm{~cm}^{-1}$ ( $\mathrm{fwhh}=15.4 \mathrm{~cm}^{-1}$ ) in good agreement with the predicted value of $17234 \mathrm{~cm}^{-1}$ obtained according to the empirical equation of Frey and Horrocks ${ }^{[31]}$ for an $\mathrm{Eu}^{\mathrm{III}}$ ion with ninefold coordination by six heterocyclic nitrogen atoms and three amide oxygen atoms. ${ }^{[15]}$ We can safely conclude that the coordination geometry around the $\mathrm{Eu}^{\mathrm{III}}$ luminescent probe is very similar in $(\mathrm{HHH})-\left[\mathrm{EuZn}\left(\mathrm{L}^{i}\right)_{3}\right]^{5+}(i=1,3)$ and corresponds to a facial pseudotricapped trigonal-prismatic arrangement, as found in the crystal structure of (HHH)$\left[\operatorname{EuZn}\left(\mathrm{L}^{1}\right)_{3}\right]^{5+}$. As expected, the methyl groups bound to the bidentate binding unit in $\mathrm{L}^{1}$ and $\mathrm{L}^{3}$ have minor-to-negligible effects on the coordination sphere of $\mathrm{Eu}^{\mathrm{III}}$. The $\mathrm{Eu}\left({ }^{5} \mathrm{D}_{0}\right)$ lifetime measured upon selective excitation of the ${ }^{5} \mathrm{D}_{0}$ level of 5 at $13 \mathrm{~K}(2.52 \mathrm{~ms}$, Table 2$)$ is only slightly longer than that reported for $(\mathrm{HHH})-\left[\mathrm{EuZn}\left(\mathrm{L}^{1}\right)_{3}\right]^{5+}(2.19 \mathrm{~ms}$ at $10 \mathrm{~K}) .^{[15]}$

Table 2. Lifetimes $\tau$ [ms] of the $\operatorname{Eu}\left({ }^{5} \mathrm{D}_{0}\right)$ excited level for [LnM$\left.\left(\mathrm{L}^{3}\right)_{3}\right]\left(\mathrm{ClO}_{4}\right)_{5}(5-8)$ under various excitation conditions (analyzing wavelengths set at the maximum of the ${ }^{5} \mathrm{D}_{0} \rightarrow{ }^{7} \mathrm{~F}_{2}$ transition).

\begin{tabular}{llcll}
\hline Compound & State & $T[\mathrm{~K}]$ & $\lambda_{\text {exc }}[\mathrm{nm}]$ & $\tau[\mathrm{ms}]$ \\
\hline$\left[\operatorname{EuZn}\left(\mathrm{L}^{3}\right)_{3}\right]^{5+}(\mathbf{5})$ & solid & 13 & 378 & $2.63(1)$ \\
& solid & 13 & 580.7 & $2.52(1)$ \\
& solid & 77 & 378 & $2.65(1)$ \\
& solid & 77 & 580.7 & $2.52(1)$ \\
& solid & 295 & 378 & $2.53(1)$ \\
& solid & 295 & 580.4 & $2.36(1)$ \\
& solid & 295 & 308 & $2.68(1)$ \\
& solution $^{[a]}$ & 295 & 378 & $2.89(2)$ \\
{$\left[\mathrm{EuFe}\left(\mathrm{L}^{3}\right)_{3}\right]^{5+}(\mathbf{7})$} & solution $^{[\mathrm{a}]}$ & 295 & 580.6 & $2.88(2)$ \\
& solid & 13 & 308 & $0.277(7)$ \\
& solid & 295 & 308 & $0.129(1)$ \\
{$\left[\mathrm{Gd}(\mathrm{Eu}) \mathrm{Fe}\left(\mathrm{L}^{3}\right)_{3}\right]^{5+}(\mathbf{8})$} & solution & 295 & 308 & $0.059(1)$ \\
& solid & 13 & 308 & $0.283(9)$ \\
& solid & 295 & 308 & $0.143(3)$ \\
\hline[
\end{tabular}

[a] $3.7 \times 10^{-3} \mathrm{M}$ in dry acetonitrile.
The emission spectra obtained for $\left[\mathrm{EuFe}\left(\mathrm{L}^{3}\right)_{3}\right]\left(\mathrm{ClO}_{4}\right)_{5} \cdot \mathrm{H}_{2} \mathrm{O}$ (7) at $13 \mathrm{~K}$ by excitation through the excited states of the ligand $\left(\lambda_{\mathrm{exc}}=32467\right.$ or $\left.26667 \mathrm{~cm}^{-1}\right)$ are comparable to those observed for $\mathbf{5}$, in spite of an overall weaker intensity and a broadening of the bands (Figure $4 \mathrm{~b}$ ). The ${ }^{5} \mathrm{D}_{0} \rightarrow{ }^{7} \mathrm{~F}_{0}$ transition is still unique; however, it is faint and appears at the same energy $\left(17221 \mathrm{~cm}^{-1}\right)$ as that found for $\mathbf{5}$. The splitting of the ${ }^{7} \mathrm{~F}_{\mathrm{j}}$ levels in $\mathbf{7}$ and $\mathbf{5}$ and the relative integrated intensity ratio of ${ }^{5} \mathrm{D}_{0} \rightarrow{ }^{7} \mathrm{~F}_{\mathrm{j}}(j=1-4)$ transitions $(1.00,1.33,0.10,1.33$ in $\mathbf{7}$ and $1.00,1.31,0.10,1.00$ in $\mathbf{5})$ are very similar and point to comparable $\mathrm{Eu}^{\mathrm{III}}$ coordination spheres in both complexes. However, the $\operatorname{Eu}\left({ }^{5} \mathrm{D}_{0}\right)$ lifetime is reduced by a factor of 9.5 when going from 5 (2.63(1) $\mathrm{ms})$ to $7(0.277(7) \mathrm{ms}$, Table 2). This can be reasonably assigned to an $\mathrm{Eu} \rightarrow \mathrm{Fe}^{\mathrm{II}}{ }_{\text {hs }}$ energy transfer which partially deactivates Eu-centered luminescence. Similar studies with the analogous $\mathrm{Gd}^{\mathrm{III}}$ complex $\left[\mathrm{GdFe}\left(\mathrm{L}^{3}\right)_{3}\right]\left(\mathrm{ClO}_{4}\right)_{5} \cdot 2 \mathrm{H}_{2} \mathrm{O}(\mathbf{8})$ doped with $2 \%$ Eu lead to the same results $(\tau=0.283(9) \mathrm{ms})$ which rules out self-quenching processes involving $\mathrm{Eu}^{\mathrm{III}}$ ions occurring in the crystal. At $295 \mathrm{~K}$, the $\mathrm{Eu}\left({ }^{5} \mathrm{D}_{0}\right)$ lifetime is further reduced by a factor of 2 , but the broadened emission spectrum still shows the characteristic Eu-centered luminescence (Figure 4c).

In acetonitrile, the complexes $(\mathrm{HHH})-\left[\operatorname{LnM}\left(\mathrm{L}^{3}\right)_{3}\right]^{5+}[\mathrm{Ln}=$ $\mathrm{La}, \mathrm{Eu} ; \mathrm{M}=\mathrm{Zn}, \mathrm{Fe}$ ) exhibit strong $\pi \rightarrow \pi^{*}$ absorption bands in the UV region, as similarly found for analogous complexes with $\mathrm{L}^{1}{ }^{[2,15]}$ The absorption spectra of $(\mathrm{HHH})-\left[\mathrm{LnFe}\left(\mathrm{L}^{3}\right)_{3}\right]^{5+}$ $(\mathrm{Ln}=\mathrm{La}, \mathrm{Eu})$ in the $6250-26300 \mathrm{~cm}^{-1}$ range are characteristic of high-spin $\mathrm{Fe}^{\mathrm{II}}$ complexes. ${ }^{[10,27]}$ The shoulder at $\approx 22220 \mathrm{~cm}^{-1}\left(\varepsilon \approx 500 \mathrm{M}^{-1} \mathrm{~cm}^{-1}\right)$, which is responsible for the yellow color of the complexes, is assigned to the $\mathrm{Fe}^{\mathrm{II}}{ }_{\mathrm{hs}} \rightarrow \pi^{*}$ MLCT transition, as observed for 7 in the solid state. Compared to the related $\mathrm{Fe}_{\text {ls }}^{\mathrm{II}} \rightarrow \pi^{*}$ MLCT band at $19010 \mathrm{~cm}^{-1}\left(\varepsilon=5800 \mathrm{M}^{-1} \mathrm{~cm}^{-1}\right)$ for the pure low-spin complexes $(\mathrm{HHH})-\left[\mathrm{LnFe}\left(\mathrm{L}^{1}\right)_{3}\right]^{5+}(\mathrm{Ln}=\mathrm{La}, \mathrm{Eu}){ }^{[2]}$ the MLCT band of the high-spin analogue is much weaker and blueshifted by $\approx 3200 \mathrm{~cm}^{-1}$. The spin-allowed $\mathrm{d}-\mathrm{d}$ transition of $(\mathrm{HHH})-\left[\mathrm{LnFe}\left(\mathrm{L}^{3}\right)_{3}\right]^{5+}\left(\mathrm{Ln}=\mathrm{La}, \mathrm{Eu} ;{ }^{5} \mathrm{~T}_{2 \mathrm{~g}} \rightarrow{ }^{5} \mathrm{E}_{\mathrm{g}}\right.$ in idealized $O_{\mathrm{h}}$ microsymmetry) appears in the near-IR region as a split band $\left(10990 \mathrm{~cm}^{-1} ; \varepsilon=14 \mathrm{M}^{-1} \mathrm{~cm}^{-1}\right.$ and $\left.8850 \mathrm{~cm}^{-1} ; \varepsilon=11 \mathrm{M}^{-1} \mathrm{~cm}^{-1}\right)$ which is diagnostic of pseudooctahedral high-spin $\mathrm{Fe}^{\mathrm{II}}$ complexes distorted by dynamic Jahn - Teller effects. ${ }^{[32]}$ When we consider the complete absorption spectrum of (HHH)$\left[\mathrm{LnFe}\left(\mathrm{L}^{3}\right)_{3}\right]^{5+}$, we can conclude that $\mathrm{Fe}^{\mathrm{II}}$ hs provides a semitransparent spectral window in the range $20000-12000 \mathrm{~cm}^{-1}$ (Figure $5 \mathrm{a}$ ), while intense MLCT transitions associated with $\mathrm{Fe}_{\text {ls }}^{\mathrm{II}}$ obscure the related domain $\left(20000-14000 \mathrm{~cm}^{-1}\right)$ in (HHH)-[LnFe $\left.\left(\mathrm{L}^{1}\right)_{3}\right]^{5+}$ (Figure $5 \mathrm{~b}$ ). The emission spectrum of $(\mathrm{HHH})-\left[\mathrm{EuZn}\left(\mathrm{L}^{3}\right)_{3}\right]^{5+}$ in acetonitrile is very similar to that observed in the solid state, except for the expected broadening of the bands. The $\operatorname{Eu}\left({ }^{5} \mathrm{D}_{0}\right)$ lifetime is longer in solution $(2.88 \mathrm{~ms})$, as previously reported for other analogous complexes. ${ }^{[2,15,33]}$ The absolute quantum yield $\left(\Phi=3.0 \times 10^{-3}\right.$, Table 3) is comparable with those reported for (HHH)$\left[\operatorname{EuZn}\left(\mathrm{L}^{1}\right)_{3}\right]^{5+}\left(\Phi=1.7 \times 10^{-3}\right)^{[15]}$ and $(\mathrm{HHH})-\left[\operatorname{EuZn}\left(\mathrm{L}^{2}\right)_{3}\right]^{5+}$ $\left(\Phi=3.4 \times 10^{-3}\right) .^{[2]}$ The substitution of $\mathrm{Zn}^{\text {II }}$ by $\mathrm{Fe}^{\mathrm{II}}{ }_{\text {hs }}$ in 7 decreases the quantum yield by two orders of magnitude as a result of intramolecular $\mathrm{Eu} \rightarrow \mathrm{Fe}^{\mathrm{II}}{ }_{\text {hs }}$ energy transfers. However, the quenching process is only partial and leads to a weak, but detectable Eu-centered luminescence $\left(\Phi=1.1 \times 10^{-5}\right.$, 

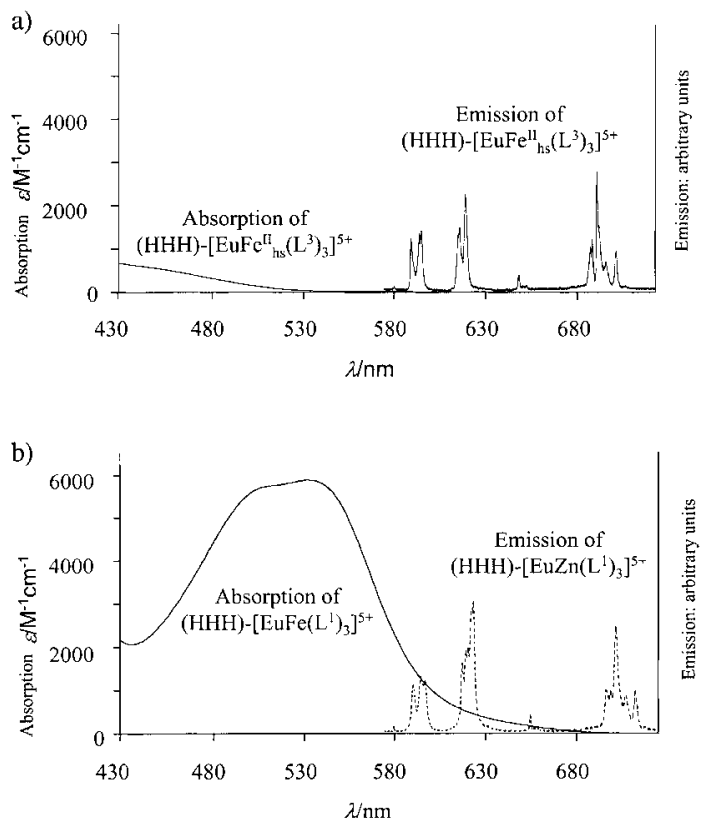

Figure 5. Comparison between the absorption spectrum (in acetonitrile, $298 \mathrm{~K}$ ) and the emission spectrum (in the solid state, $13 \mathrm{~K}$ ) of a) $(\mathrm{HHH})$ $\left[\mathrm{EuFe}^{\mathrm{II}}{ }_{\mathrm{hs}}\left(\mathrm{L}^{3}\right)_{3}\right]^{5+}$ and b) the spin crossover complex $(\mathrm{HHH})-\left[\mathrm{EuFe}\left(\mathrm{L}^{1}\right)_{3}\right]^{5+}$. As no emission can be detected for $(\mathrm{HHH})-\left[\mathrm{EuFe}\left(\mathrm{L}^{1}\right)_{3}\right]^{5+}$, the emission spectrum of $(\mathrm{HHH})-\left[\operatorname{EuZn}\left(\mathrm{L}^{1}\right)_{3}\right]^{5+}$ is shown (dashed line) in order to highlight the spectral overlap.

Table 3. Quantum yields $\left(\Phi_{\text {rel }}\right)$ relative to $\left[\mathrm{Eu}(\text { terpy })_{3}\right]^{3+}\left(\right.$ terpy $=2,2^{\prime}: 6^{\prime}, 2^{\prime \prime}$ terpyridine) for $(\mathrm{HHH})-\left[\operatorname{EuM}\left(\mathrm{L}^{3}\right)_{3}\right]^{2+}(\mathrm{M}=\mathrm{Zn}, \mathrm{Fe})$ in acetonitrile $(3.7 \times$ $\left.10^{-3} \mathrm{M} ; 298 \mathrm{~K}\right)$.

\begin{tabular}{llllll}
\hline Compound & Conc. & $\lambda_{\text {exc }}[\mathrm{nm}]$ & $\varepsilon_{\text {exc }}\left[\mathrm{M}^{-1} \mathrm{~cm}^{-1}\right]$ & $\Phi_{\text {rel }}^{[a]}$ & $\Phi_{\text {abs }}^{[\mathrm{b}]}$ \\
\hline$\left[\operatorname{Eu}(\text { terpy })_{3}\right]^{3+[\mathrm{cc}]}$ & $1.0 \times 10^{-3}$ & 371 & 549 & 1.0 & $1.3 \times 10^{-2}$ \\
{$\left[\operatorname{EuZn}\left(\mathrm{L}^{1}\right)_{3}\right]^{5+[\mathrm{d}]}$} & $1.0 \times 10^{-3}$ & 395 & 555 & 0.13 & $1.7 \times 10^{-3}$ \\
{$\left[\operatorname{EuZn}\left(\mathrm{L}^{3}\right)_{3}\right]^{5+}(\mathbf{5})$} & $6.0 \times 10^{-3}$ & 395 & 420 & 0.23 & $3.0 \times 10^{-3}$ \\
{$\left[\operatorname{EuFe}\left(\mathrm{L}^{3}\right)_{3}\right]^{5+}(\mathbf{7})$} & $6.0 \times 10^{-3}$ & 400 & 840 & $8.3 \times 10^{-4}$ & $1.1 \times 10^{-5}$ \\
\hline
\end{tabular}

[a] Relative errors on $\Phi_{\text {rel }}$ are typically $10-15 \%$. [b] The quantum yields of $\left.[\text { Eu(terpy })_{3}\right]^{3+}$ relative to an aerated water solution of $\left[\mathrm{Ru}(\text { bipy })_{3}\right]^{2+}$ is 0.47 which allows the calculation of absolute quantum yields. ${ }^{[41]}$ [c] Quantum yields are determined relative to $\left[\mathrm{Eu}(\text { terpy })_{3}\right]^{3+}\left(10^{-3} \mathrm{M}\right.$ in acetonitrile). [d] Taken from reference [15].

Table 3) which is comparable with that observed for $\left[\mathrm{Eu}\left(N, N, N^{\prime}, N^{\prime} \text {-tetraethylpyridine-2,6-dicarboxamide }\right)_{3}\right]^{3+}$ $\left(\Phi=8.6 \times 10^{-5}\right){ }^{[34]}$ As there is no orbitally mediated communication between $\mathrm{Fe}^{\mathrm{II}}$ and $\mathrm{Eu}^{\mathrm{III}}$ in $(\mathrm{HHH})-\left[\mathrm{EuZn}\left(\mathrm{L}^{i}\right)_{3}\right]^{5+}(i=$ $1-3$, intermetallic distances $\approx 9.0 \AA),{ }^{[2,15]}$ the $\mathrm{Eu} \rightarrow \mathrm{Fe}^{\mathrm{II}}$ energy transfer relies on the Förster mechanism and depends on the spectral overlap between the "Eu ${ }^{\mathrm{III}}$-centered" emission spectrum and the "Fe $\mathrm{Fe}^{\mathrm{II}}$-centered" absorption spectrum. Figure 5 shows these spectra for the pure high-spin complex $(\mathrm{HHH})-\left[\mathrm{EuFe}\left(\mathrm{L}^{3}\right)_{3}\right]^{5+}$ and for the spin-crossover complex $(\mathrm{HHH})-\left[\mathrm{EuFe}\left(\mathrm{L}^{1}\right)_{3}\right]^{5+}$ in acetonitrile. The results lead to the straightforward conclusion that the simultaneous blue-shift of the MLCT and red-shift of the $\mathrm{d}-\mathrm{d}$ transitions in the " $\mathrm{Fe}^{\mathrm{II}} \mathrm{hs}^{-}$ centered" absorption spectrum significantly reduce spectral overlap with the red Eu-centered emission to give less efficient intramolecular $\mathrm{Eu} \rightarrow \mathrm{Fe}^{\mathrm{II}}$ energy transfers.

\section{Conclusion}

With respect to $L^{1}$, the introduction of a methyl substituent at the 6 position of the terminal pyridine ring in $\mathrm{L}^{3}$ affects the selectivity of the assembly process and leads to the heterodimetallic triple-stranded helicates $(\mathrm{HHH})-\left[\mathrm{LnM}\left(\mathrm{L}^{3}\right)_{3}\right]^{5+}$ $(\mathrm{M}=\mathrm{Fe}, \mathrm{Zn})$. However, the use of stoichiometric conditions $\left(\mathrm{Ln}: \mathrm{M}: \mathrm{L}^{3}=1: 1: 3\right)$ combined with a large total concentration of the ligand $(\geq 10 \mathrm{~mm}$ ) overcomes the decreased enthalpic driving force and produces quantitatively the desired entropystabilized edifices. The $(\mathrm{HHH})-\left[\mathrm{LnM}\left(\mathrm{L}^{3}\right)_{3}\right]^{5+}(\mathrm{M}=\mathrm{Fe}, \mathrm{Zn})$ complexes display structural properties very similar to those previously established for their analogues with the 5-methylsubstituted ligand in $(\mathrm{HHH})-\left[\operatorname{LnM}\left(\mathrm{L}^{1}\right)_{3}\right]^{5+}$, as ascertained by high-resolution emission spectroscopy in the solid state and by NMR in solution. The only significant difference results from interstrand steric constraints between the terminal methyl groups in $(\mathrm{HHH})-\left[\mathrm{LnM}\left(\mathrm{L}^{3}\right)_{3}\right]^{5+}$ which limit the contraction of the $\mathrm{M}-\mathrm{N}$ bonds. This effect is critical for $\mathrm{Fe}^{\mathrm{II}}$ which is forced to adopt a pure high-spin electronic configuration in (HHH)$\left[\mathrm{LnFe}\left(\mathrm{L}^{3}\right)_{3}\right]^{5+}$, while room-temperature spin-crossover behavior characterizes the complexes $(\mathrm{HHH})-\left[\operatorname{LnFe}\left(\mathrm{L}^{1}\right)_{3}\right]^{5+}$. This programmed feature allows the detailed spectroscopic investigations of Eu-centered emission in a EuFe pair containing $\mathrm{Fe}^{\mathrm{II}}$ hs and we eventually demonstrate that an intramolecular $\mathrm{Eu} \rightarrow \mathrm{Fe}_{\text {hs }}^{\mathrm{II}}$ energy transfer (multipolar Förster mechanism) partially obscures $\mathrm{Eu}^{\mathrm{III}}$ luminescence in (HHH)-[EuFe$\left.\left(\mathrm{L}^{3}\right)_{3}\right]^{5+}$. On the other hand, $\mathrm{Fe}_{\text {ls }}^{\mathrm{II}}$ quantitatively quenches Eu-centered luminescence in $(\mathrm{HHH})-\left[\operatorname{EuFe}\left(\mathrm{L}^{1}\right)_{3}\right]^{5+}$, which can be rationalized by the spectral overlap between the absorption of the $\mathrm{Fe}^{\mathrm{II}}$ ${ }_{\mathrm{s}}$ chromophore and the emission of $\mathrm{Eu}^{\mathrm{III}}$. According to these concepts, we can predict that the green Tbcentered luminescence in $(\mathrm{HHH})-\left[\mathrm{TbFe}\left(\mathrm{L}^{1}\right)_{3}\right]^{5+}$ and $(\mathrm{HHH})-$ $\left[\mathrm{TbFe}\left(\mathrm{L}^{3}\right)_{3}\right]^{5+}$ would experience a severe intramolecular quenching process since the ${ }^{5} \mathrm{D}_{4} \rightarrow{ }^{7} \mathrm{~F}_{\mathrm{j}}(j=0-6)$ transitions are located at higher energies compared to $\mathrm{Eu}^{\mathrm{III}}$ and exhibit considerable overlap with the MLCT transitions of both highand low-spin Fe ${ }^{\mathrm{II}}$. This application is currently under investigation in our laboratories together with the fine-tuning of Eu-centered luminescence through a judicious external tuning of the electronic state of $\mathrm{Fe}^{\mathrm{II}}$.

\section{Experimental Section}

Solvents and starting materials: These were purchased from Fluka AG (Buchs, Switzerland) and used without further purification unless otherwise stated. Thionyl chloride was distilled from elemental sulfur; acetonitrile, dichloromethane and triethylamine were distilled from $\mathrm{CaH}_{2}$. Silica gel (Acros, $0.035-0.07 \mathrm{~mm}$ ) was used for preparative column chromatography. 6-( $N, N$-Diethylcarbamoyl)- $N$-methyl- $N$ - $\left\{4^{\prime}-\left[4^{\prime \prime}\right.\right.$-(methylamino)-3"'-nitrobenzyl]-2'-nitrophenyl pyridine-2-carboxamide $(\mathbf{1})^{[2]}$ and 6-methylpyridine-2-carboxylic acid $(\mathbf{2})^{[35]}$ were prepared according to literature procedures. The perchlorate salts $\mathrm{Ln}\left(\mathrm{ClO}_{4}\right)_{3} \cdot n \mathrm{H}_{2} \mathrm{O}(\mathrm{Ln}=\mathrm{La}, \mathrm{Eu}, \mathrm{Gd})$ were prepared from the corresponding oxides (Rhodia, 99.99\%) and dried according to published procedures. ${ }^{[36]}$ The Ln content of solid salts was determined by complexometric titrations with Titriplex III (Merck) in the presence of urotropine and xylene orange. ${ }^{[37]} \mathrm{Fe}\left(\mathrm{ClO}_{4}\right)_{2} \cdot 6 \mathrm{H}_{2} \mathrm{O}$ was purchased from Aldrich.

Caution: Dry perchlorates may explode and should be handled in small quantities and with the necessary precautions. ${ }^{[38]}$ 


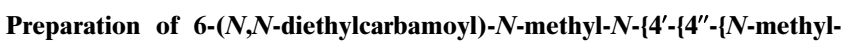
$N$-[(6"'-methylpyridine-2'"'-yl)carbonyl $]$ amino $))-3^{\prime \prime}$-nitrobenzyl $\}-2^{\prime}$-nitrophenyl\}pyridine-2-carboxamide (3): A mixture of $2(566 \mathrm{mg}, 4.13 \mathrm{mmol})$, thionyl chloride $(3.0 \mathrm{~mL}, 41 \mathrm{mmol})$, and DMF $(0.2 \mathrm{~mL})$ was refluxed for $90 \mathrm{~min}$ in dry dichloromethane $(40 \mathrm{~mL})$. The mixture was evaporated and dried under vacuum. The solid residue was dissolved in dichloromethane $(75 \mathrm{~mL})$ and added dropwise to a solution of $\mathbf{1}(715 \mathrm{mg}, 1.37 \mathrm{mmol})$ and triethylamine $(1.0 \mathrm{~mL}, 7.2 \mathrm{mmol})$ in dichloromethane $(75 \mathrm{~mL})$. The solution was refluxed for $15 \mathrm{~h}$ under an inert atmosphere. After the mixture had been cooled, water $(100 \mathrm{~mL})$ was added and the organic layer was separated. The aqueous phase was extracted with dichloromethane $(5 \times$ $100 \mathrm{~mL})$. The combined organic phases were dried $\left(\mathrm{Na}_{2} \mathrm{SO}_{4}\right)$ and evaporated. The crude product was purified by column chromatography (silica gel, $\left.\mathrm{CH}_{2} \mathrm{Cl}_{2} / \mathrm{MeOH} 97: 3\right)$ to give 5 (855 mg, $1.34 \mathrm{mmol}$; yield $98 \%$ ) as a yellow solid. M.p. $65-70{ }^{\circ} \mathrm{C} ;{ }^{1} \mathrm{H}$ NMR $\left(300 \mathrm{MHz}, \mathrm{CDCl}_{3}\right): \delta=0.84-1.25$ (m, 6H), 2.08-4.07 (m, 15H), 6.96-8.17 (m, 12 H); ES-MS: $\mathrm{m} / \mathrm{z}(\%): 761$ (70) $[M+\mathrm{H}]^{+}$

\section{Preparation of 2-\{6-(N,N-diethylcarbamoyl)pyridin-2-yl\}-1,1'-dimethyl-} 5,5'-methylene-2' -(6-methylpyridine-2-yl)bis[1H-benzimidazole] $\left(L^{3}\right)$ : Activated iron powder $(2.3 \mathrm{~g}, 41 \mathrm{mmol})$ and concentrated hydrochloric acid $(37 \%, 8.3 \mathrm{~mL}, 99 \mathrm{mmol})$ were added to a solution of $\mathbf{3}(855 \mathrm{mg}, 1.34 \mathrm{mmol})$ in ethanol/water $(260 \mathrm{~mL} / 70 \mathrm{~mL})$. The mixture was refluxed for $15 \mathrm{~h}$ under an inert atmosphere, excess iron was filtered off, ethanol was distilled under vacuum, and water $(50 \mathrm{~mL})$ was added. A solution of $\mathrm{H}_{4}$ EDTA $(19.6 \mathrm{~g})$ and $\mathrm{NaOH}(5.4 \mathrm{~g})$ in water $(100 \mathrm{~mL})$ was poured into the resulting mixture, and dichloromethane $(300 \mathrm{~mL})$ was added. The resulting stirred mixture was neutralized $(\mathrm{pH}=7.0)$ with concentrated aqueous $\mathrm{NH}_{4} \mathrm{OH}$ solution. Concentrated $\mathrm{H}_{2} \mathrm{O}_{2}$ solution $(30 \%, 1.1 \mathrm{~mL})$ was added under vigorous stirring, and the $\mathrm{pH}$ was adjusted to 8.5 with aqueous $\mathrm{NH}_{4} \mathrm{OH}$ solution. The organic layer was separated and the aqueous phase extracted with dichloromethane $(3 \times 100 \mathrm{~mL})$. The combined organic phases were dried $\left(\mathrm{Na}_{2} \mathrm{SO}_{4}\right)$ and evaporated, and the crude product purified by column chromatography (silica gel, $\mathrm{CH}_{2} \mathrm{Cl}_{2} / \mathrm{MeOH}$ 98:2), and then crystallized from a dichloromethane/hexane mixture to give $\mathrm{L}^{3}(597 \mathrm{mg}, 1.10 \mathrm{mmol}$; yield $82 \%)$ as a white solid. M.p. $=125^{\circ} \mathrm{C} ;{ }^{1} \mathrm{H}$ NMR $\left(300 \mathrm{MHz}, \mathrm{CDCl}_{3}\right)$ : $\delta=1.09\left(\mathrm{t}, J^{3}=7 \mathrm{~Hz}, 3 \mathrm{H}\right), 1.26\left(\mathrm{t}, J^{3}=7 \mathrm{~Hz}, 6 \mathrm{H}\right), 2.60(\mathrm{~s}, 3 \mathrm{H}), 3.31\left(\mathrm{q}, J^{3}=\right.$ $7 \mathrm{~Hz}, 2 \mathrm{H}), 3.57$ (q, $\left.J^{3}=7 \mathrm{~Hz}, 2 \mathrm{H}\right), 4.17(\mathrm{~s}, 3 \mathrm{H}), 4.23(\mathrm{~s}, 3 \mathrm{H}), 4.25(\mathrm{~s}, 2 \mathrm{H})$, $7.19(\mathrm{~m}, 3 \mathrm{H}), 7.30\left(\mathrm{~d}, J^{3}=9 \mathrm{~Hz}, 2 \mathrm{H}\right), 7.53\left(\mathrm{~d}, J^{3}=8 \mathrm{~Hz}, 1 \mathrm{H}\right), 7.69(\mathrm{~m}, 3 \mathrm{H})$, $7.90\left(\mathrm{t}, J^{3}=8 \mathrm{~Hz}, 1 \mathrm{H}\right), 8.15\left(\mathrm{~d}, J^{3}=8 \mathrm{~Hz}, 1 \mathrm{H}\right), 8.36\left(\mathrm{~d}, J^{3}=8 \mathrm{~Hz}, 1 \mathrm{H}\right)$; ${ }^{13} \mathrm{C}$ NMR $\left(75 \mathrm{MHz}, \mathrm{CDCl}_{3}\right.$ ): $\delta=13.1,14.6,24.7,32.9,33.0\left(\mathrm{C}_{\text {prim }}\right) ; 40.0$, 42.5, $43.2\left(\mathrm{C}_{\mathrm{sec}}\right) ; 110.0,110.1,119.9,120.1,121.9,122.9,123.4,124.9,125.2$, 125.3, 137.2, 138.1 $\left(\mathrm{C}_{\text {tert }}\right) ; 136.0,136.1,136.6,136.9,142.9,149.6,150.0,150.6$, 154.5, 157.6, $168.6\left(\mathrm{C}_{\text {quat }}\right)$; EI-MS: $\mathrm{m} / z(\%): 543(29)\left[M^{+}\right]$.

Preparation of $\left[\mathrm{LnZn}\left(\mathrm{L}^{3}\right)_{3}\right]\left(\mathrm{ClO}_{4}\right)_{5} \cdot \mathrm{H}_{2} \mathrm{O}(\mathrm{Ln}=\mathrm{La}, 4 ; \mathbf{E u}, 5)$ : An equimolar solution of $\mathrm{Ln}\left(\mathrm{ClO}_{4}\right)_{3} \cdot n \mathrm{H}_{2} \mathrm{O}(\mathrm{Ln}=\mathrm{La}, \mathrm{Eu})$ and $\mathrm{Zn}\left(\mathrm{ClO}_{4}\right)_{2} \cdot 6 \mathrm{H}_{2} \mathrm{O}$ in acetonitrile $(92.5 \mathrm{~mm}, 271 \mu \mathrm{L})$ was added to a solution of $\mathrm{L}^{3}(40.8 \mathrm{mg}$, $75.0 \mu \mathrm{mol})$ in $1: 2 \mathrm{CH}_{2} \mathrm{Cl}_{2} / \mathrm{MeCN}(3 \mathrm{~mL})$. After the mixture had been stirred for $1 \mathrm{~h}$ at room temperature, the solution was evaporated, the solid residue dissolved in $\mathrm{MeCN}(2 \mathrm{~mL})$, and $\mathrm{Et}_{2} \mathrm{O}$ was diffused into the solution for $1 \mathrm{~d}$. The resulting white microcrystalline powders were collected by filtration and dried to give $\left[\operatorname{LnZn}\left(\mathrm{L}^{3}\right)_{3}\right]\left(\mathrm{ClO}_{4}\right)_{5} \cdot \mathrm{H}_{2} \mathrm{O}(\mathbf{4}$ and 5$)$ in $64-69 \%$ yield. 4: Elemental analysis calcd (\%) for $\mathrm{LaZnC}_{99} \mathrm{H}_{101} \mathrm{~N}_{21} \mathrm{O}_{24} \mathrm{Cl}_{5}$ (2350.6): $\mathrm{C}$ 50.59, H 4.33, N 12.51; found: C 50.55, H 4.35, N 12.44 .

5: Elemental analysis calcd (\%) for $\mathrm{EuZnC}_{99} \mathrm{H}_{101} \mathrm{~N}_{21} \mathrm{O}_{24} \mathrm{Cl}_{5}$ (2363.6): $\mathrm{C}$ 50.31, H 4.31, N 12.44; found: C 50.33, H 4.38, N 12.45.

Preparation of $\left[\mathrm{LnFe}\left(\mathrm{L}^{3}\right)_{3}\right]\left(\mathrm{ClO}_{4}\right)_{5} \cdot n \mathrm{H}_{2} \mathrm{O} \cdot x \mathrm{MeCN}(\mathrm{Ln}=\mathrm{La}, n=2, x=$ 1.5: 6; $\operatorname{Ln}=\mathrm{Eu}, \boldsymbol{n}=1, x=0$ : 7; $\operatorname{Ln}=\mathbf{G d}: E u$ (98:2), $n=2, x=0: 8$ ): To a solution of $\mathrm{L}^{3}(48.3 \mathrm{mg}, 88.8 \mu \mathrm{mol})$ and $\mathrm{Ln}\left(\mathrm{ClO}_{4}\right)_{3} \cdot n \mathrm{H}_{2} \mathrm{O}(\mathrm{Ln}=\mathrm{La}, \mathrm{Eu})$ $(29.6 \mu \mathrm{mol})$ in degassed acetonitrile $(3 \mathrm{~mL})$ was added a solution of $\mathrm{Fe}\left(\mathrm{ClO}_{4}\right)_{2} \cdot n \mathrm{H}_{2} \mathrm{O}(29.6 \mu \mathrm{mol})$ in acetonitrile $(1 \mathrm{~mL})$. After the mixture had been stirred for $1 \mathrm{~h}$ at room temperature, the solution was evaporated, the solid residue dissolved in $\mathrm{MeCN}(3 \mathrm{~mL})$ and $\mathrm{Et}_{2} \mathrm{O}$ was diffused into the solution for $2 \mathrm{~d}$. The resulting yellow crystals were collected by filtration and dried to give complexes $\left[\mathrm{LnFe}\left(\mathrm{L}^{3}\right)_{3}\right]\left(\mathrm{ClO}_{4}\right)_{5} \cdot n \mathrm{H}_{2} \mathrm{O} \cdot x \mathrm{MeCN}(6$ and 7) in $43-66 \%$ yield. The Eu-doped Gd complex 8 was prepared by replacing the lanthanide solution by a mixed solution of $\mathrm{Eu} / \mathrm{Gd}(98: 2)$.

6: Elemental analysis calcd (\%) for $\mathrm{LaFeC}_{102} \mathrm{H}_{107.5} \mathrm{~N}_{22.5} \mathrm{O}_{25} \mathrm{Cl}_{5}$ (2420.5): C 50.61, H 4.48, N 13.02; found: C 50.61, H 4.42, N 13.05 .

7: Elemental analysis calcd (\%) for $\mathrm{EuFeC}_{99} \mathrm{H}_{101} \mathrm{~N}_{21} \mathrm{O}_{24} \mathrm{Cl}_{5}$ (2354.1): C 50.51, H 4.32, N 12.50; found: C 50.61, H 4.34, N 12.54 .
8: Elemental analysis calcd (\%) for $\mathrm{GdFeC}_{99} \mathrm{H}_{103} \mathrm{~N}_{21} \mathrm{O}_{25} \mathrm{Cl}_{5}$ (2377.4): C 50.02, H 4.37, N 12.37; found: C 49.92, H 4.39, N 12.31.

Preparation of $\left[\mathbf{Z n}_{2}\left(\mathbf{L}^{3}\right)_{2}\right]\left(\mathbf{C l O}_{4}\right)_{4}:\left[\mathrm{Zn}_{2}\left(\mathrm{~L}^{3}\right)_{2}\right]\left(\mathrm{ClO}_{4}\right)_{4}$ was prepared in situ for ${ }^{1} \mathrm{H}$ NMR studies. A solution of $\mathrm{Zn}\left(\mathrm{ClO}_{4}\right)_{2} \cdot 6 \mathrm{H}_{2} \mathrm{O}$ in acetonitrile $(108 \mathrm{~mm}, 121 \mu \mathrm{L})$ was added to a solution of $\mathrm{L}^{3}(7.1 \mathrm{mg}, 13 \mu \mathrm{mol})$ in $1: 2$ $\mathrm{CH}_{2} \mathrm{Cl}_{2} / \mathrm{MeCN}(1.5 \mathrm{~mL})$. After the mixture had been stirred for $1 \mathrm{~h}$ at room temperature, the solution was evaporated under vacuum, and the solid residue was dissolved in $\mathrm{CD}_{3} \mathrm{CN}(700 \mu \mathrm{L})$.

Spectroscopic and analytical measurements: Reflectance spectra were recorded as finely ground powders dispersed in $\mathrm{MgO}(5 \%)$ with $\mathrm{MgO}$ as reference on a Perkin-Elmer Lambda 900 spectrophotometer equipped with a PELA-1020 integrating sphere from Labsphere. UV/Vis electronic spectra were recorded at $20^{\circ} \mathrm{C}$ in $10^{-3} \mathrm{M}$ solutions of MeCN with a PerkinElmer Lambda 900 spectrometer in quartz cells (path length: 0.1 and $1 \mathrm{~cm}$ ). Spectrophotometric titrations were performed with a J\&M diode array spectrometer (Tidas series) connected to an external computer. In a typical experiment, $\mathrm{L}^{3}(25 \mathrm{~mL})$ in acetonitrile $(0.1 \mathrm{~mm})$ was titrated at $20^{\circ} \mathrm{C}$ with an equimolar (1.00 mM) solution of $\mathrm{Ln}\left(\mathrm{ClO}_{4}\right)_{3} \cdot n \mathrm{H}_{2} \mathrm{O}$ and $\mathrm{M}\left(\mathrm{ClO}_{4}\right)_{2}$. $n \mathrm{H}_{2} \mathrm{O}\left(\mathrm{M}^{\mathrm{II}}=\mathrm{Zn}, \mathrm{Fe}\right)$ in acetonitrile under an $\mathrm{N}_{2}$ atmosphere. After each addition of $0.10 \mathrm{~mL}$, the absorbances were recorded with Hellma optrodes (optical path length: 0.1 and $0.5 \mathrm{~cm}$ ) immersed in the thermostated titration vessel and connected to the spectrometer. Mathematical treatment of the spectrophotometric titrations was performed with factor analysis ${ }^{[20]}$ and with the SPECFIT program. ${ }^{[21]}$ IR spectra were obtained from $\mathrm{KBr}$ pellets with a Perkin Elmer 883 spectrometer. ${ }^{1} \mathrm{H}$ NMR spectra were recorded at $25^{\circ} \mathrm{C}$ on a Broadband Varian Gemini 300 spectrometer. Chemical shifts are given in ppm with respect to TMS. EI-MS $(70 \mathrm{eV})$ were recorded with VG$7000 \mathrm{E}$ and Finnigan-4000 instruments. Pneumatically-assisted electrospray (ES-MS) mass spectra were recorded from $10^{-4} \mathrm{~mol} \mathrm{dm}^{-3}$ acetonitrile solutions on API III and API 365 tandem mass spectrometers (PE Sciex) by infusion at $4-10 \mu \mathrm{Lmin}^{-1}$. The spectra were recorded under low up-front declustering or collision-induced dissociation (CID) conditions, typically $\Delta V=0-30 \mathrm{~V}$ between the orifice and the first quadrupole of the spectrometer. The experimental procedures for high-resolution, laserexcited luminescence measurements have been published previously. ${ }^{[39]}$ Solid-state samples were finely powdered and low temperatures (77 or $13 \mathrm{~K}$ ) were achieved by means of a Cryodyne Model 22 closed-cycle refrigerator from CTI Cryogenics. Luminescence spectra were corrected for the instrumental function, but not the excitation spectra. Lifetimes are averages of at least three to five independent determinations. Ligand excitation and emission spectra were recorded on a Perkin-Elmer LS-50B spectrometer equipped for low-temperature measurements. The relative quantum yields were calculated with the formula given in Equation (5). ${ }^{[33]}$

$Q_{\mathrm{x}} / Q_{\mathrm{r}}=\left\langle A_{\mathrm{r}}\left(\lambda_{\mathrm{r}}\right) / A_{\mathrm{x}}\left(\lambda_{\mathrm{x}}\right)\right\rangle\left\langle I\left(\lambda_{\mathrm{r}}\right) / I\left(\lambda_{\mathrm{x}}\right)\right\rangle\left\langle n_{\mathrm{x}}^{2} / n_{\mathrm{r}}^{2}\right\rangle\left\langle D_{\mathrm{x}} / D_{\mathrm{r}}\right\rangle$

Where subscript $\mathrm{r}$ stands for the reference and $\mathrm{x}$ for the samples; $A$ is the absorbance at the excitation wavelength, $I$ is the intensity of the excitation light at the same wavelength, $n$ is the refractive index (1.341 for solutions in $\mathrm{MeCN}$ ) and $D$ is the measured integrated luminescence intensity. Cyclic voltammograms were recorded with a BAS CV-50W potentiostat connected to a personal computer. A three-electrode system consisting of a stationary Pt or glass carbon disk working electrode, a Pt counterelectrode and a nonaqueous $\mathrm{Ag} / \mathrm{AgCl}$ reference electrode was used. $\mathrm{NBu}_{4} \mathrm{PF}_{6}(0.1 \mathrm{M}$ in $\mathrm{MeCN})$ served as an inert electrolyte. The reference potential $\left(E^{0}=\right.$ $-0.12 \mathrm{~V}$ vs SCE$)$ was standardized against $\left[\mathrm{Ru}(\mathrm{bpy})_{3}\right]\left(\mathrm{ClO}_{4}\right)_{2}\left(\mathrm{bpy}=2,2^{\prime}\right.$ bipyridyl). ${ }^{[40]}$ The scan speed was $100 \mathrm{mV} \mathrm{s}^{-1}$ and voltammograms were analyzed according to established procedures. ${ }^{[0]}$

Magnetic data for samples in acetonitrile were obtained by the Evans' method according to the detailed procedure described in reference [2] and using a Varian Gemini 300 spectrometer. The diamagnetic contributions of the ligand $\mathrm{L}^{3}$ and the perchlorate anions in the heterodimetallic complex $\left[\mathrm{LaFe}\left(\mathrm{L}^{3}\right)_{3}\right]\left(\mathrm{ClO}_{4}\right)_{5}$ were obtained from the molar diamagnetic susceptibility measured for $\left[\mathrm{LaZn}\left(\mathrm{L}^{1}\right)_{3}\right]\left(\mathrm{ClO}_{4}\right)_{5}$ with the Evans' method $\left(m^{\text {dia }}=\right.$ $\left.0.0159 \mathrm{~g} \mathrm{~cm}^{-3}, \delta \tilde{\nu}^{\mathrm{dia}}=-7.1 \mathrm{~Hz}\right){ }^{[2]}$ Molar magnetic susceptibilities of $[\mathrm{La}-$ $\left.\mathrm{Fe}\left(\mathrm{L}^{3}\right)_{3}\right]\left(\mathrm{ClO}_{4}\right)_{5}$ were measured at $10 \mathrm{~K}$ intervals between 233 and $333 \mathrm{~K}$, corrected for diamagnetism and converted to effective magnetic moments $\mu_{\text {eff }}$ (or $\chi T$ ) according to Equation (6), where $m^{\text {p }}$ and $m^{\text {dia }}$ are the $\mu_{\text {eff }}=2.828 \sqrt{\frac{T}{v_{0} S_{\mathrm{f}}}\left[\frac{\delta v^{\mathrm{p}} M^{\mathrm{p}}}{m^{\mathrm{p}}}-\frac{\delta v^{\mathrm{dia}} M^{\mathrm{dia}}}{m^{\mathrm{dia}}}\right]}=2.828 \sqrt{\chi T}$ 
concentrations of the paramagnetic solute and its diamagnetic analogue respectively $\left[\mathrm{g} \mathrm{cm}^{-3}\right], \delta \tilde{\nu}^{\mathrm{p}}$ and $\delta \tilde{v}^{\text {dia }}$ the chemical shift differences $[\mathrm{Hz}]$ between the resonances of the reference compound in the two coaxial tubes ( $\delta \tilde{v}>0$ for paramagnetism, $\delta \tilde{v}<0$ for diamagnetism), $M^{\mathrm{p}}$ and $M^{\text {dia }}$ the molecular masses of the paramagnetic and diamagnetic compounds respectively $\left[\mathrm{g} \mathrm{mol}^{-1}\right], T$ is the absolute temperature, $\mu_{\text {eff }}$ the effective magnetic moment $\left[\mu_{\mathrm{B}}\right]$ and $S_{\mathrm{f}}$ the shape factor of the magnet.

To avoid complications associated with possible partial decomplexation, the magnetic susceptibilities of $\left[\mathrm{LaFe}\left(\mathrm{L}^{3}\right)_{3}\right]\left(\mathrm{ClO}_{4}\right)_{5}$ were recorded for total ligand concentrations of $24 \mathrm{~mm}$. Solid-state volume magnetic susceptibilities were obtained with a SQUID magnetometer Quantum Design modelMPMS5 operating at a magnetic field strength of $3000 \mathrm{Oe}$, in the range $1.9-300 \mathrm{~K}$. The data were corrected for diamagnetism with $\left[\mathrm{LaZn}\left(\mathrm{L}^{3}\right)_{3}\right]\left(\mathrm{ClO}_{4}\right)_{5} \cdot \mathrm{H}_{2} \mathrm{O} \quad\left(\mathbf{4}, \quad \chi^{\mathrm{dia}}=-2.92 \times 10^{-4} \mathrm{~cm}^{3} \mathrm{~mol}^{-1}\right)$. Elemental analyses were performed by Dr. H. Eder from the microchemical Laboratory of the University of Geneva

\section{Acknowledgements}

We are grateful to Véronique Foiret for technical assistance. C.E. thanks Givaudan (F. Hoffmann-La Roche) for a fellowship and J.-C.B. thanks the Fondation Herbette (Lausanne) for the gift of spectroscopic equipment. This work is supported through grants from the Swiss National Science Foundation.

[1] a) O. Kahn, Adv. Inorg. Chem. 1995, 43, 179, and references therein; b) M. Andruh, I. Ramade, E. Codjovi, O. Guillou, O. Kahn, J.-C. Trombe, J. Am. Chem. Soc. 1993, 115, 1822; c) I. Ramade, O. Kahn, Y. Jeannin, F. Robert, Inorg. Chem. 1997, 36, 930; d) M. L. Kahn, C. Mathonière, O. Kahn, Inorg. Chem. 1999, 38, 3692; e) C. Benelli, A. C. Fabretti, A. Giusti, J. Chem. Soc. Dalton Trans. 1993, 409; f) M. Sakamoto, M. Hashimura, K. Matsuki, N. Matsumoto, K. Inoue, H. Ottawa, Bull. Chem. Soc. Jpn 1991, 64, 3639; g) C. Benelli, A. Caneschi, D. Gatteschi, O. Guillou, L. Pardi, Inorg. Chem. 1990, 29, 1750 ; h) J.-P. Costes, F. Dahan, A. Dupuis, J.-P. Laurent, Inorg. Chem. 1996, 35, 2400; i) J.-P. Costes, F. Dahan, A. Dupuis, J.-P. Laurent, Inorg. Chem. 1997, 36, 3429; j) J.-P. Costes, F. Dahan, A. Dupuis, J.-P. Laurent, Chem. Eur. J. 1998, 4, 1616; k) J.-P. Costes, F. Dahan, A. Dupuis, Inorg. Chem. 2000, 39, 165; 1) J.-P. Costes, F. Dahan, A. Dupuis, J.-P. Laurent, Inorg. Chem. 2000, 39, 169; m) Z. Xu, P. W. Read, D. E. Hibbs, M. B. Hursthouse, K. M. A. Malik, B. O. Patrick, S. J. Rettig, M. Seid, D. A. Summers, M. Pink, R. C. Thompson, C. Orvig, Inorg. Chem. 2000, 39, 508; n) M. Sasaki, K. Manseki, H. Horiuchi, M. Kumagai, M. Sakamoto, H. Dakiyama, Y. Nishida, M. Sakai, Y. Sadaoka, M. Ohba, H. Okawa, J. Chem. Soc. Dalton Trans. 2000, 259.

[2] a) C. Piguet, E. Rivara-Minten, G. Bernardinelli, J.-C. G. Bünzli, G. Hopfgartner, J. Chem. Soc. Dalton Trans. 1997, 421; b) C. Edder, C. Piguet, G. Bernardinelli, J. Mareda, C. G. Bochet, J.-C. G. Bünzli, G. Hopfgartner, Inorg. Chem. 2000, 39, 5059.

[3] a) F. S. Richardson, Chem. Rev. 1982, 82, 541; b) W. deW. Horrocks, Jr., D. R. Sudnick, Acc. Chem. Res. 1981, 14, 384; c) C. F. Meares, S. M. Yeh, L. Stryer, J. Am. Chem. Soc. 1981, 103, 1607; d) W. deW. Horrocks, Jr., B. Holmquist, B. L. Vallee, Proc. Nat. Acad. Sci. USA 1975, 72, 4764; e) C. K. Luk, Biochemistry 1971, 10, 2838; f) E. T. O'Keeffe, R. L. Hill, J. E. Bell, Biochemistry 1980, 19, 4954.

[4] a) D. L. Dexter, J. Chem. Phys. 1953, 21, 836; b) B. Schlicke, P. Belser, L. De Cola, E. Sabbioni, V. Balzani, J. Am. Chem. Soc. 1999, 121, 4207.

[5] a) G. F. de Sá, O. L. Malta, C. de Mello Donega, A. M. Simas, R. L. Longo, P. A. Santa-Cruz, E. F. da Silva, Jr., Coord. Chem. Rev. 2000, 196, 165; b) O. Malta, F. R. G. Silva, Spectrochim. Acta 1998, A54, 1593.

[6] a) T. Förster, Ann. Phys. 1948, 55; b) T. Förster, Discuss. Faraday Soc. 1959, $27,7$.

[7] a) I. M. Clarkson, A. Beeby, J. I. Bruce, L. J. Govenlock, M. P. Lowe, C. E. Mathieu, D. Parker, K. Senanayake, New J. Chem. 2000, 24, 377; b) J.-C. G. Bünzli in Lanthanide Probes in Life, Chemical and Earth Sciences (Eds.: J.-C. G. Bünzli, G. R. Choppin), Elsevier, Amsterdam, 1989, Chapter 7.
[8] a) P. A. Brayshaw, J.-C. G. Bünzli, P. Froidevaux, J. M. Harrowfield, Y. Kim, A. N. Sobolev, Inorg. Chem. 1995, 34, 2068; b) P. Guerriero, P. A. Vigato, J.-C. G. Bünzli, E. Moret, J. Chem. Soc. Dalton. Trans. 1990, 647; c) J.-C. G. Bünzli, P. Froidevaux, C. Piguet, New J. Chem. 1995, 19, 661; d) P. Froidevaux, J.-C. G. Bünzli, J. Phys. Chem. 1994, 98, 53; e) J. J. Lessmann, W. deW. Horrocks, Jr., Inorg. Chem. 2000, 39, 3114; f) S. T. Frey, C. A. Chang, J. F. Carvalho, A. Varadarajan, L. M. Schultze, K. L. Pounds, W. deW. Horrocks, Jr., Inorg. Chem. 1994, 33, 2882; g) W. deW. Horrocks, Jr., M.-J. Rhee, A. P. Snyder, D. R. Sudnick, J. Am. Chem. Soc. 1980, 102, 365; h) C. Piguet, J.-C. G. Bünzli, G. Bernardinelli, G. Hopfgartner, A. F. Williams, J. Am. Chem. Soc. 1993, 115, 8197; i) C. Platas, M. Elhabiri, M. Hollenstein, J.-C. G. Bünzli, C. Piguet, J. Chem. Soc. Dalton Trans. 2000, 2031; j) R. C. Howell, K. V. N. Spence, I. A. Kahwa, D. J. Williams, J. Chem. Soc. Dalton Trans. 1998, 2727.

[9] a) P. Gütlich, A. Hauser, H. Spiering, Angew. Chem. 1994, 106, 2109; Angew. Chem. Int. Ed. Engl. 1994, 33, 2024; b) H. Toftlund, Coord. Chem. Rev. 1989, 94, 67.

[10] a) L. J. Charbonnière, A. F. Williams, C. Piguet, G. Bernardinelli, E. Rivara-Minten, Chem. Eur. J. 1998, 4, 485; b) D. Onggo, J. M. Hook, A. D. Rae, H. A. Goodwin, Inorg. Chim. Acta 1990, 173, 19; c) A. Diebold, K. S. Hagen, Inorg. Chem. 1998, 37, 215; d) W. Linert, M. Konecny, F. Renz, J. Chem. Soc. Dalton Trans. 1994, 1523; e) P. Lainé, A. Gourdon, Inorg. Chem. 1995, 34, 5129.

[11] a) L. J. Wilson, D. Georges, M. A. Hoselton, Inorg. Chem. 1975, 14, 2968; b) F. A. Deeney, C. J. Harding, G. M. Morgan, V. McKee, J. Nelson, S. J. Teat, W. Clegg, J. Chem. Soc. Dalton Trans. 1998, 1837.

[12] F. Renz, H. Oshio, V. Ksenofontov, M. Waldeck, H. Spiering, P. Gütlich, Angew. Chem. 2000, 112, 3832; Angew. Chem. Int. Ed. 2000, 39, 3699.

[13] a) J. I. Bruce, R. S. Dickins, L. J. Govenlock, T. Gunnlaugsson, S. Lopinski, M. P. Lowe, D. Parker, R. D. Peacock, J. J. B. Perry, S. Aime, M. Botta, J. Am. Chem. Soc. 2000, 122, 9674; b) M. P. Lowe, D. Parker, Chem. Commun. 2000, 707; c) A. Beeby, R. S. Dickins, S. Fitzgerald, L. J. Govenlock, C. L. Maupin, D. Parker, J. P. Riehl, G. Siligardi, J. A. G. Williams, Chem. Commun. 2000, 1183; d) D. Parker, Coord. Chem. Rev. 2000, 205, 109; e) O. Reany, T. Gunnlaugsson, D. Parker, J. Chem. Soc. Perkin Trans. 2 2000, 1819; f) D. Parker, P. K. Senanayake, J. A. G. Williams, J. Chem. Soc. Perkin Trans. 2 1998, 2129; g) A. P. De Silva, D. B. Fox, A. J. M. Huxley, T. S. Moody, Coord. Chem. Rev. 2000, 205, 41.

[14] S. Mahapatra, N. Gupta, R. Mukherjee, J. Chem. Soc. Dalton Trans. 1991, 2911.

[15] C. Piguet, J.-C. G. Bünzli, G. Bernardinelli, G. Hopfgartner, S. Petoud, O. Schaad, J. Am. Chem. Soc. 1996, 118, 6681.

[16] C. Piguet, B. Bocquet, G. Hopfgartner, Helv. Chim. Acta 1994, 77, 931.

[17] C. Piguet, G. Bernardinelli, G. Hopfgartner, Chem. Rev. 1997, 97, 2005.

[18] a) G. Hopfgartner, C. Piguet, J. D. Henion, J. Am. Soc. Mass Spectrom. 1994, 5, 748; b) G. Hopfgartner, F. Vilbois, C. Piguet, Rapid Commun. Mass Spectrom. 1999, 13, 302.

[19] C. Piguet, G. Hopfgartner, B. Bocquet, O. Schaad, A. F. Williams, $J$. Am. Chem. Soc. 1994, 116, 9092.

[20] E. R. Malinowski, D. G. Howery, Factor Analysis in Chemistry, Wiley, New York, Chichester, 1980.

[21] H. Gampp, M. Maeder, C. J. Meyer, A. D. Zuberbühler, Talanta 1986, 33, 943.

[22] a) Y. Ducommun, K. E. Newman, A. E. Merbach, Inorg. Chem. 1980, 19, 3696; b) I. Bertini, C. Luchinat, Coord. Chem. Rev. 1996, 150, 77

[23] K. Nakamoto, Infrared and Raman Spectra in Inorganic and Coordination Compounds, Wiley, New York, 5th ed., 1997, Part A, p. 199.

[24] a) M. Kotani, J. Phys. Soc. Japan 1949, 4, 293; b) B. N. Figgis, Nature 1958, 182, 1568; c) J. S. Griffith, Trans. Farad. Soc. 1958, 1109; d) E. König, A. S. Chakravarty, Theoret. Chim. Acta 1967, 9, 151; e) J. P. Jesson, J. F. Weiher, S. Trofimenko, J. Chem. Phys. 1968, 48, 2058.

[25] O. Kahn, Molecular Magnetism, VCH, Weinheim, 1993, Chap. 2.

[26] C. J. O'Connor, Prog. Inorg. Chem. 1982, 26, 203.

[27] E. C. Constable, G. Baum, E. Bill, R. Dyson, R. van Eldik, D. Fenske, S. Kaderli, D. Morris, A. Neubrand, M. Neuburger, D. R. Smith, K. Wieghardt, M. Zehnder, A. D. Zuberbühler, Chem. Eur. J. 1999, 5, 498.

[28] L. L. Martin, R. L. Martin, K. S. Murray, A. M. Sargeson, Inorg. Chem. 1990, 29, 1387. 
[29] a) D. F. Evans, J. Chem. Soc. 1959, 2003; b) T. H. Crawford, J. Swanson, J. Chem. Educ. 1971, 48, 382; c) J. Löliger, R. Scheffold, J. Chem. Educ. 1972, 49, 646; d) D. S. Raiford, C. L. Fisk, E. D. Becker, Anal. Chem. 1979, 51, 2050; e) M. V. Baker, L. D. Field, T. W. Hambley, Inorg. Chem. 1988, 27, 2872; f) D. H. Grant, J. Chem. Educ. 1995, 72, 39.

[30] C. Piguet, J. Chem. Educ. 1997, 74, 815.

[31] S. T. Frey, W. deW. Horrocks, Jr., Inorg. Chim. Acta 1995, 229, 383.

[32] a) F. A. Cotton, M. D. Meyers, J. Am. Chem. Soc. 1960, 62, 5023; b) H. Toftlund, S. Yde-Andersen, Acta Chem. Scand. A 1981, 35, 575; c) A. B. P. Lever, Inorganic Electronic Spectroscopy, 2nd ed, Elsevier, Amsterdam, 1984, p. 458.

[33] C. Piguet, J.-C. G. Bünzli, G. Bernardinelli, C. G. Bochet, P. Froidevaux, J. Chem. Soc. Dalton Trans. 1995, 83.

[34] F. Renaud, C. Piguet, G. Bernardinelli, J.-C. G. Bünzli, G. Hopfgartner, Chem. Eur. J. 1997, 3, 1646.
[35] G. Black, E. Depp, B. B. Corson, J. Org. Chem. 1949, 14, 14.

[36] J. F. Desreux in Lanthanide Probes in Life, Chemical and Earth Sciences (Eds.: J.-C. G. Bünzli, G. R. Choppin), Elsevier, Amsterdam, 1989, Chapter 2, p. 43.

[37] G. Schwarzenbach, Complexometric Titrations; Chapman \& Hall, London, 1957, p. 8.

[38] W. C. Wolsey, J. Chem. Educ. 1978, 50, A335.

[39] C. Piguet, A. F. Williams, G. Bernardinelli, E. Moret, J.-C. G. Bünzli, Helv. Chim. Acta 1992, 75, 1697.

[40] A. J. Bard, L. R. Faulkner, Electrochemical Methods, Fundamentals and Applications, Wiley, New York, Chichester, Brisbane, Toronto, Singapore, 1980.

41] S. Petoud, J.-C. G. Bünzli, K. J. Schenk, C. Piguet, Inorg. Chem. 1997, $36,1345$.

Received: December 18, 2000 [F2943] 